\title{
9
}

\section{Decolonising River Restoration: Restoration as Acts of Healing and Expression of Rangatiratanga}

When one thinks through how a restored river is or could be produced within the context of historical and ongoing entanglements of Indigenous peoples and settler-colonial societies, it is critical to consider what restoration is and how it is enacted within particular environmental practices. In this chapter, we look specifically at river restoration and what constitutes a restored river (or landscape and waterscapes) in the context of the Waipā River. Over the last three decades, an ever-expanding and diverse body of scholarship on river restoration has emerged; including research from the fields of historical ecology (Beller et al. 2016; Bhatt et al. 2016; Kurashima et al. 2017; Stein et al. 2010), geomorphology (Abernethy and Rutherfurd 1998; Arnaud et al. 2015; Jacobson et al. 2011), engineering (Palmer et al. 2014), environmental management (Bhatt et al. 2016; Morandi et al. 2014; Waltham et al. 2014). The emphasis remains placed on the need to address the degradation of places, ecosystems, or keystone species through targetted restoration efforts. Across the diversity of disciplines, despite the critiques of the climax approach, the "value of a historical

The original version of this chapter was revised: The incorrect information with reference to The Waikato River Authority text has now been revised and updated. The correction to this chapter is available at https://doi.org/10.1007/978-3-030-61071-5_12 
perspective" continues to be noted for setting "the goals, strategies and targets" for river restoration (Beller et al. 2020). Ecological restoration is, thus, broadly framed as the "need to protect and restore both habitat remnants and modified ecosystems in management" with reference to "the value of ecosystems as cultural landscapes" (Beller et al. 2020). Yet, critical questions still need to be raised about whose "historical perspective" is being taken into account when the restoration goals, targets, and approaches are being set, and whose cultural landscapes and waterscapes are valued when decisions are being made about what is being restored and/or protected and how the restoration practices are being enacted.

Given that river restoration is predicated on acknowledgement of past mistakes (that human actions resulted in highly degraded freshwater systems), we argue that it is important to spend time critically analysing the ideas, approaches, and practices that underpin restoration projects. The intellectual underpinnings of restoration are explored in-depth by other scholars; however, the limitations of these past studies is that they only consider Western ontological and epistemological frameworks, narrating restoration projects through the experiences of Euro-Western environmentalists, and failing to destabilise nature-culture binaries (Hall 2005; Higgs 2003; Higgs et al. 2014; Hourdequin and Havlick 2016). More recent scholarship does demonstrate that ecological restoration is not the sole domain of scientific knowledge and expertise and that Indigenous and Local Knowledges can contribute towards restoration practices (Crow et al. 2018, 2020; Ens et al. 2012; Fox et al. 2017; Ratana et al. 2019; Reyes-García et al. 2019). Furthermore, the social dimensions of landscapes and waterscapes are increasingly acknowledged, and the ways in which different knowledge systems and values influence how different groups of people define restoration priorities and facilitate restoration practices (Failing et al. 2013; Fernández-Manjarrés et al. 2018; Kibler et al. 2018; Paterson-Shallard et al. 2020; Stein et al. 2010).

River restoration (both in theory and practice), however, remains largely located within the realm of the hegemonic knowledge systems, socio-cultural values, and human-environmental relations of EuroWestern cultures. Restoration practitioners (focused on restoring the functioning of ecosystems) act in the "silent interests of ecosystems" (Hall 2005 , p. 11) and in doing so, rearticulate the long-standing commandand-control paradigm especially prevalent in freshwater management. 
We argue that ecological restoration (specifically river restoration) is not a neutral (scientific, linear, universal) process, but one that is laden with power, authority, and ontological politics. Every time an ecological restoration project commences, a particular type of 'nature' is being expressed and enacted. Restoration practitioners, therefore, are making decisions (both conscious and unconscious) about what they want a specific place and/or ecosystem to become in the future; restoration, therefore, involves the act of envisioning or transformative changes to landscape and waterscape motivated by the desires to address environmental degradation in reference to historical reconstructions of the past (which are particular imaginative geographies that are embedded within Euro-Western knowledges and ongoing colonialism).

\section{The Emergence of Ecological Restoration as a Field of Study and Practice}

A unifying theme within early restoration scholarship was to "re-create historical associations" (Jordan and Lubick 2011, p. 2). Put simply, initial ecological restoration research and restoration projects were directed at trying to return an ecosystem (a river, a forest, an island) to a prior state (often historic and/or pre-human) (Beller et al. 2016; Humphries and Winemiller 2009; Palmer et al. 2005; Palmer et al. 2016). Such early ecological restoration work was underpinned by climax theory, coined in 1916 by plant ecologist Frederic Clements, which proposed that in the absence of external shocks or disturbances, ecosystems transition through various states till they each a stable condition (climax) (Clements 1916, 1936). In the absence of disruptions, according to the theory, ecosystems would reverse to a steady state. Within restoration activities, the theory of climax was evident in the use of 'reference ecosystem' (or a historic baseline) for which practitioners direct their efforts to return an ecosystem to a former (reference) state of being (Jordan 2003; Jordan and Lubick 2011). Later ecologists disproved climax theory on multiple occasions. Non-equilibrium ecological theories increasingly gained popularity (informed by theories of self-organisation and chaos). Such theories complicated ecological restoration by demonstrating that ecosystems are 
highly complex, dynamic, and uncertain, particularly in response to changes (Higgs et al. 2014; Palmer et al. 2016; Perring et al. 2015; von Wehrden et al. 2012). The singular aim of restoration ecology (as well as conservation biology and invasion biology) to return ecosystems to a historical state (often a highly idealised one) was no longer a suitable guide for ecological restoration efforts.

Recent definitions of ecological restoration generally avoid a complete commitment to entirely recreating past (pre-human) ecosystems and instead emphasise addressing environmental degradation. The Society for Ecological Restoration International, a network founded in 1987 for restoration practitioners, for instance, defines ecological restoration as:

the process of assisting the recovery of an ecosystem that has been degraded, damaged, or destroyed ... [E]cological restoration seeks to 'assist recovery' of a natural or semi-natural ecosystem rather than impose a new direction or form upon it. That is, the activity of restoration places an ecosystem on a trajectory of recovery so that it can persist and its species can adapt and evolve. (Tipa and Nelson 2017; Wehi and Lord 2017)

Other authors define ecological restoration as a "sequence of steps progressing from ascertaining the natural and anthropogenic disturbance regimes, identifying and implementing restorative measures, and monitoring key indicators to determine trajectories of the responses and the outcomes of the restoration project" (Lake et al. 2017, p. 509). Since ecosystems are dynamic entities that flux and change over time, restoration projects thus are increasingly framed as a process of transition "a continuous coming into a being of an ecosystem" (Higgs 2003, pp. 110-111). In most restoration projects, environmental scientists and management practitioners work to restore a degraded ecosystem to a historic "baseline" or criteria of prior conditions. The baseline is often a selected reference point that is defined (by scientists) as the imagined peak of ecosystem diversity and functionality, which in settler societies is often situated before European colonisation, a tendency that is critiqued in our analysis. Scholars identify three key principles for efficient and effective ecological restoration practices. Firstly, efficient restoration establishes and maintains the values of ecosystems. Secondly, effective 
restoration maximises beneficial outcomes at the same time as costs (in terms of time, effort, and resources) are minimised. And thirdly, successful restoration involves practitioners engaging with stakeholders and partners in a way that promotes participation and enhances people's experience of ecosystems (McDonald et al. 2018; Weber et al. 2018).

A significant amount of research and on-the-ground restoration projects are focused on riparian zones (the interface between land and water that encompasses riverbanks and channels). The majority of river restoration practices are directed at the removal of invasive plants, replanting of native vegetation, and fencing off waterways from non-native fauna (to decrease grazing pressures and effluent). Within river channels, there is also a focus on restoring habitat structure, improving fish migration pathways, and augmenting refuges for fauna (particularly in the context of drought). However, restoration scholars argue that the restoration of entire river catchments and connectivity between landscapes and waterscapes remain significant challenges. Indeed, despite small and large-scale efforts to restore freshwater systems around the globe over the last two decades (particularly in the settler-states of Australia, Aotearoa, Canada and the United States), many rivers, lakes, streams, and wetlands remain in a state of worsening environmental degradation (Davenport et al. 2010; Fernández-Manjarrés et al. 2018; Hamilton et al. 2018; Marshall et al. 2017; Paterson-Shallard et al. 2020; Saulters 2014).

\section{Critiques of Ecological Restoration}

When ecological restoration as first positioned as a new paradigm that would address environmental degradation, critiques emerged from Western philosophers. For instance in Eric Katz's The Big Lie, first published in 1992, restoration is critiqued for promoting human beings domination and control over nature as well as the production of restored ecosystems that were social artefacts not 'nature'. Likewise, Australian philosopher Robert Elliot claimed the restoration efforts were merely deceptions that 'faked' nature (Elliot 1997). Elliot's central thesis is that restored landscapes are technological productions presented as of equal value to so-called 'wild nature'. Both Katz and Elliot were concerned that 
restoration efforts subverted the goals of environmental protection in that it would be used to encourage environmental offsetting; developments could be authorised on the basis that damaged environments could be simply reproduced elsewhere.

The aim of 'historical fidelity'-returning to an 'original' or predisturbance-served to legitimise restoration within the natural sciences and safeguarded it from philosophical critiques (Beller et al. 2016; Stein et al. 2010). Although a commendable purpose, and maintaining their commitment to local historical place-based associations, restoration practitioners rejected charges of command-and-control or technical approach that disputed environmental preservationist thinking. Philosopher Andrew Light adopted a pragmatic viewpoint, drawing a distinction between malicious and benevolent restoration based on the intention and claims behind ecological restoration projects (Light 1994). Light supported restoration and argued that it could play a significant role in cultivating ecological citizenship (what other scholars term an environmental ethic) that posits that ethical responsibilities for nature are part of being a good citizen (Bauman and O'Brien 2019; Katz and Light 2013; MacGregor 2014). In his 2002 book, Nature by Design, Canadian anthropologist and restoration ecologist Eric Higgs outlined four essential qualities that enabled restoration projects to be "morally good". Firstly, a project must restore ecological integrity. Secondly, restoration must be underpinned by historical knowledge. Thirdly, a project needed to include a component of "wild design" that provided space for "nature and culture ... to go wild". And fourthly, a restoration project must practise "focal restoration" that can "rebuild our concern with things that matter" (Higgs 2003, pp. 226, 285). Ecological restoration, thus, was conceptualised to be both an ecological and socially important practice that can alter human and more-than-human relationships.

The main theoretical criticisms of ecological restoration discourses were initially limited in that most remain largely within the confines of Western ontological and epistemological frameworks that rearticulate the nature-culture dichotomy. In settler societies like Australia, the United States, and Aotearoa restoration projects often continue to be premised on settler-relationships with land, water, and coasts (Connelly and Knuth 2002; Davenport et al. 2010; Moran 2010; Peters et al. 2015; Schuelke 
2014). Indeed, as Callicott aptly notes, the "simple and easy understanding of the appropriate norm for ecological restoration is premised on two myths that then prevailed-the wilderness myth and the ecologicalequilibrium myth" (Callicott 2002, p. 418).

In Chap. 3 of this book, we describe how the colonial discourse of an 'untamed' and 'uncultivated' nature was used to justify settler colonialism in Aotearoa, including the invasion of the Waikato and the dispossession of Māori. In different settler societies, variations of the 'wilderness myth' (terra nullius, Australia's Outback, Aotearoa's wastelands, and Canada's empty Arctic North) were used to downplay, deny or erase Indigenous peoples from their landscapes, waterscapes and seascapes (Baldwin et al. 2011; Cameron 2015; Clover and Historical Society of the Hauraki Plains 2007; Fitzmaurice 2007; Giblett 2009; Pluymers 2011; Veracini 2010). In the Australian context, for instance, the year 1788 (the start of British colonisation in Australia) is frequently employed as the baseline for restoration work with limited recognition given to Australian Indigenous peoples' thousands of years of occupation and complex ways of managing environments (Beilin and West 2016, p. 193). When environmental scientists, particularly those ascribing to the notion of a timeless stable climax ecosystem, did recognise Indigenous presence it was to criticise Indigenous peoples' for disrupting 'pristine' nature with their use of local ecosystems, use of fire, and loss of biodiversity (Flannery 2002; Head 2012).

In Australia, where the history of Aboriginal peoples' occupation stretches 60,000 years, the idea of a "balanced" and "pre-human" state is completely out of check with the socio-cultural and environmental histories (Barber and Jackson 2015; Bardsley and Wiseman 2016; Bashford 2013; Beilin and West 2016, p. 193; Langton 2006; Winter 2019). Likewise, in Aotearoa, as we and countless other scholars demonstrate, Europeans did not arrive to an empty land ('terra nullius') but to instead a country filled with waterscapes and landscapes that generations of Māori iwi (tribe), hapū (subtribe), and whānau (family) carefully created, maintained and cared for (Anderson 2003; Anderson 2002; Boswijk et al. 2005; Park 2018; Stokes 2000). Moreover, the conceptualisation of 'pristine nature', wherein European settlers arrived to settle an 
unoccupied and a-historical place, is forcefully challenged by Indigenous scholars (ourselves included) for its Eurocentric framing of nature.

Indigenous ontologies, as well highlight throughout this book, connect human and more-than-human communities in ongoing reciprocal (often kinship-based) relationships (de Leeuw and Hunt 2018; Todd 2014; Watts 2013; Winter 2018). From Māori worldviews, culture and nature are inextricably interwoven together to the extent that one cannot exist without the other (Clément 2017; Salmond 2014). These ontological and epistemological differences, however, feature into accounts of ecological restoration theorising or practices. Yet as we discuss throughout this book, a river for Māori (and many other Indigenous peoples) is not something that exists as a mere entity that human actors inscribe meaning on (altering and using, commanding-and-controlling, degrading and restoring). From Māori perspectives, rivers (like other geoentities) are more-than-human actors with agency, power, and a life force (as well as being the kin to particular iwi and hapū). Rivers are, therefore, from a Māori ontological viewpoint, materially and metaphysically coconstituted; simultaneously affecting and affected by others (human and more-than-human). Thus, since both these two myths (of supposedly empty undeveloped 'wilderness'/'wastelands' as well as ecosystemequilibrium) are now largely rejected, the ethical and theoretical foundations of ecological restoration in settler societies are being increasingly uncertain and complex (Pearce 2019).

The narrative of historicising and romanticising Indigenous cultures, in wherein they are confined to "pre-history" or "traditional", remains prevalent within ecological restoration. The narrative overlooks not only Indigenous histories of land and water management, their economies, and political authority but also attempts to rob Indigenous peoples of their futures and capacities to adapt to changing circumstances (Head 2012). The idea of a historical baseline or year zero (1788 in Australia, 1840 in Aotearoa) reinforces the notion that Indigenous peoples, communities, and individuals are confined to pre-history (inherently traditional, static and unchanging), which does not allow for dynamic and fluid understandings of cultures (Bennett and van Sittert 2019; Head 2012; Head and Muir 2004; Lidström et al. 2016). 
Some of the emergent ecological restoration research and projects are examining the interconnectedness of ecosystems and people, with scholars even acknowledging the presence of the plurality of ontologies and epistemologies. For instance, the idea of "eco-cultural restoration" is promoted by Dennis Martinez, founder of the Indigenous Peoples' Restoration Network. Likewise, Māori ecologist Priscilla Wehi uses the term "bi-cultural restoration" to take into account Aotearoa's Treaty partnership between two cultures (Pākehā and Mãori) and the critical importance of including "cultural practices" in restoration efforts in Aotearoa (Senos et al. 2006; Wehi et al. 2019; Wehi and Lord 2017). Such work makes a significant contribution to expanding restoration discourse, but remains at the margins of the dominant restoration praxis, and, where included, does so in projects that involve a focus on Indigenous knowledge, cultural practices, or livelihoods (Reyes-García et al. 2019; Tipa and Nelson 2017; Wehi and Lord 2017). Often this research seeks to use Indigenous Knowledge to augment gaps in Western scientific knowledge (Reyes-García et al. 2019) and to identify significant cultural sites or biota that Indigenous communities want restored (Ens et al. 2012; Long et al. 2017; White et al. 2011). Indigenous knowledge (positioned as complementary to western science) is thus often framed as a tool that can be used by restoration ecologists and practitioners to better reference ecosystems (where historical data is unavailable) and ensure that Indigenous communities support restoration projects (Uprety et al. 2012). The limited spaces afforded to Indigenous peoples within restoration scholarship (confined to the realms of Indigenous ecological knowledge, cultural practices, and livelihoods) means that the field remains underpinned (seemingly unwittingly) to colonial structures, knowledges, values, and practices; and Indigenous ways of knowing and being in the world remain tokenistically referenced. Yet, a wealth of recent work from Mãori scientists and social scientists demonstrates the tremendous capacity to expand socio-cultural, political, economic, and ecological thinking and practices in restoration beyond those of the West to encompass Indigenous and other peoples' ontologies and epistemologies (Carter 2019; Forster 2012; Harmsworth and Roskruge 2014; Hikuroa et al. 2011; Panelli and Tipa 2007; Tipa and Nelson 2017; Wehi et al. 2019). 


\section{Co-management and Restoration Planning}

Restoration of the Waipā River involves actions and participation by a range of actors operating under a variety of mandates, seeking to achieve a range of objectives and with differing funding arrangements, including iwi and hapū, the National Wetlands Trust, and community groups. We focus, in particular, on restoration efforts of iwi arising from opportunities provided by the co-governance framework and co-management arrangements. As discussed in Chap. 5, the passing of the Waipā River Act enabled access by applicants to the Waikato Clean-up River Trust (WRCuT) for restoration projects targeting the Waipā River and tributaries. In 2017, as part of its co-management arrangements (as detailed in Chaps. 5 and 6), Ngāti Maniapoto produced a report that detailed its river management and restoration priorities for the Waipā River and its tributaries. The Maniapoto Priorities Report articulates the iwi's aspirations, values and issues in relation to the Waipa and links with the Maniapoto Māori Trust Board's (MMTB) other plans as well as policies developed by the Waikato Regional Council's (WRC) such as the Waipa Catchment Plan and the Waipa Zone Management Plan (Maniapoto Maori Trust Board 2017; NIWA 2014).

The Waipā Catchment Plan was developed by WRC in conjunction with Ngāti Maniapoto through a collaborative process to guide the implementation of integrated catchment management activities within the Waipā River. The Waipā Catchment Plan identifies 100 actions points, ranging from large erosion and sediment control projects to biodiversity, to looking after peat lakes, to working with Māori landowners (WRC 2014). These action points, though not enforceable, provide the focus for WRC to undertake restoration and management within the Waipa catchment and progress is measured against attainment. Overarching the Catchment Plan is the Waipā Zone Management Plan, which sets out the high-level strategy and objectives to guide management activities 'to revitalise the waters of the Waipā River and its tributaries by 2050' (WRC 2012). The Maniapoto Priorities Report formed the basis for the Maniapoto's Waipā restoration projects (which were included within the Waipā River Restoration Strategy). 
Unlike many restoration projects, which often remove people (specifically Indigenous peoples) from the narrative, the various restoration works being undertaken by Ngāti Maniapoto are seeking to restore their cultural waterscapes and landscapes. Projects are led and managed by various layers of Maniapoto iwi/hapū/whānau, including formal iwi institutions (MMTB and Nehenehenui RMC) and informal institutions (marae-based or whānau) often in collaboration with external institutions (such as the National Institute of Water and Atmospheric Research hereafter NIWA and the Waikato River Authority hereafter WRA). Restoration projects report struggling to find sufficient and ongoing funding to support their restoration efforts. The lack of resourcing is partly a result of the limited funds available through the MMTB compared to other iwi in the Waikato region; Ngāti Maniapoto (as we outlined in Chaps. 7 and 8) are still in the process of negotiating with the central government (the Crown) for a legal and financial reparations package (known as a Treaty settlement) for historical injustices committed against the iwi by the Crown. Also, the lack of funding available to support restoration efforts is a consequence of the failures of the co-governing institution (the Waikato River Authority hereafter WRA) and its restoration funding body (the Waikato River Cleanup Trust hereafter WRCcT). The WRA was established, as we discuss in Chap. 5, as a consequence of Treaty settlements reached between five River iwi (Ngāti Maniapoto, Raukawa, Waikato Tainui, Te Arawa, and Tūwharetoa) and the Crown, and involved the Crown agreeing to share co-governance and co-management arrangements with iwi over the Waikato and Waipā rivers. The WRA administers the WRCuT which provides funding for restoration works in catchments of both rivers. However, the ways in which the WRCuT operates (specifically its process of awarding funding to restoration projects based on a yearly contestable funding round to any group doing restoration work) is heavily critiqued by our interviewees, including those who whakapapa to Maniapoto. In many respects, Maniapoto interviewees demonstrated a lack of understanding of the details of the settlement co-governance arrangements (including how WRCuT funding is awarded and to whom), and the implications of the settlement and co-governance for 
iwi members and those operating at the flax roots level. For these interviewees, their primary concerns (and criticisms) related to fairness and equity. For example, where funding is awarded to councils or industry groups, our interview participants questioned whether it was fair since these groups are generally better and more consistently resourced than iwi, hapū and whānau. For interviewees, the need to build capacity and capabilities within Maniapoto and to overcome the barriers to participating in all aspects of river restoration and management (including the competing demands on people's time), compounded the desire for fairness and equity, and the need to take steps to ensure sustainability into the future.

\section{Constraints on Restoration Efforts}

Many interviewees spoke mahi (work) on the ground was being undervalued by their own iwi institutions (MMTB), the co-governance institution (Waikato River Authority), as well as local councils. At the moment, the majority of people who are undertaking restoration projects "are doing it voluntarily on top of everything else" in their lives. In contrast, those employed in all the various institutions involved in freshwater governance and management (for MMTB, WRA, WRC, ODC) are all getting paid for their work (Māori Business Owner 1 2019). It was so difficult for hapū- and whānau-led restoration efforts, one iwi consultant reported, to access funding through the WRA managed WRCuT that whānau were overwhelmed by the process (Māori Business Owner 1 2019). Indeed, many Maniapoto whānau want to implement their own restoration projects but lack of "access to money" was the "big barrier" to transforming their aspirations for restoring their awa into actions. However, both scientists and iwi members expressed strong support resources to be directed to support the work and "aspirations ... whatever that would be" of (Māori Business Owner 1 2019; Scientist 2 2019, p. 2). "Getting a whole heap of ... submission writers" who could write funding applications to the WRA, regional council, and other funding bodies "would be amazing" because at the moment whānau are "just like no, I can't even begin to grasp the concept of what that is and what that's 
going to take" to write a submission (Māori Business Owner 1 2019). However, if a scientist or researcher assisted them to fill out the application forms and make a submission, then they would be able to translate their aspirations for restoring their awa into on-the-ground restoration works that would benefit their whānau and future generations (Māori Business Owner 1 2019).

Another constraint to river restoration work was the lack of people able to undertake the work (which was largely unpaid). For instance, the utilisation of the Stream Health Monitoring Assessment kit (SHMAK) by hapū started in 2016; however, MMTB struggled to recruit sufficient numbers of kaitiaki who would be willing to undertake testing for them within the middle and upper parts of the Waipā River Catchment. Engagement with the project is being constrained by the fact that the majority of Maniapoto (around 80 per cent) live outside of the rohe of Maniapoto. This means that only " 20 ... per cent that are left in Maniapoto ... are already highly involved in their marae, their kura [school], the kōhanga [preschool]_-everything else ... that needs to be done" (Māori Business Owner 1 2019). So, for many Māori, the duties and work involved in being a "kaitiaki" (which is mostly voluntary and unpaid labour) "just seems like another thing on top of all" their own responsibilities (to their whānau, marae, hapū). The "hardest part is getting" Maniapoto (including those who live within and outside the rohe) back to their awa (Māori Business Owner 1 2019).

Kanohi kit e kanohi [face-to-face meetings] is so crucial with Māori-like knowing who you are and what you are on about can only happen when you are standing in front of these people talking to them ... Once they're there and they realise how important this is, how amazing this is, once they've been in the water and reconnected every single person that's come has pretty much come back. It's really about getting them there in the first place to say that this is worthy of sacrificing some family time maybe or weekend time or whatever. (Māori Business Owner 1 2019)

Iwi representatives also regularly spoke of the ontological and epistemological differences between Māori and Pākehā ways of thinking and how it creates difficulties in environmental governance and management 
more broadly as well as in the context of restoration; which we discussed previously in Chaps. 3 and 4 in terms of two cultures (Pākehā and Māori) "talking past each other" due to differing worldviews (Metge and Kinloch 2014; Winter 2018). As Iwi Rep 5 states, Ngāti Maniapoto and other Māori people possess a "whakapapa directly to those tūpuna that were there" (who signed the Treaty, experienced colonial violence, dispossession and marginalisation), whereas the Crown (embodied by the officials of the New Zealand Government, its agencies, and local councils) "does not have that same sort of connection". Governments change, as do government officials, and the people who represent the Crown today do not represent their own tūpuna; (indeed, accordingly to Māori whakapapa it is "the Queen and her family" who should be directly representing their ancestors in Treaty Settlements and the co-governance of the Waipā). Thus, Iwi Rep 5 argues, central government (Crown) and local government officials (who adopt a Pākehā/Western worldview) do not carry with them the same sense of "intergenerational responsibility" that Māori do (Iwi Rep 5 2019). Such a worldview translates into freshwater governance, management, and restoration approaches continuing to employ short-term time planning horizons and favouring current development (benefits) over future environmental harms (costs).

\section{Getting the Values Right}

One iwi representative, who affiliates to both Waikato-Tainui and Ngāti Maniapoto iwi, spoke of the importance of ensuring that iwi values (encompasses socio-cultural, spiritual, political, economic and ecological dimensions) are translated from a conceptual framework into real-world environmental management plans, as well as on-the-ground management and restoration practices (Iwi Rep 8 2019). The post-Treaty settlement period is a "mediated, negotiated space" in which iwi, involved in the co-governance and co-management arrangements for the Waipā and Waikato Rivers, need to consider how their values can provide "the groundwork ... [on which] the house [is built] up" (Iwi Rep 8 2019). The importance of thinking about what values matter and how they can be 
incorporated into management plans and restoration projects relates to Māori cosmology and mātauranga Māori:

If I was to draw a picture, I'd be drawing a picture saying this is Papa-tū-ānuku [Earth Mother]. This is Ranginui [Sky Father]. How do we fit in here? How do we fit in whatever those values are, how do we make it fit in there? If it's about caring for everything that exists between these two [Papa-tū-ā-nuku and Ranginui] and including them, you can't lose [when you practice kaitiakitanga]. ... Because you can't do it the other way around. You can't take a Pākehā process and put them [Papa-tū-ā-nuku and Ranginui into it]—you can't... it wouldn't work. It ... [is] our mana. Our sovereignty and our space. [The] lens ... says [that] Papa-tū-ā-nuku's here ... It's... [a] Māori worldview. (Iwi Rep 8 2019)

The Maniapoto Cultural Health Assessment Framework is one such framework that seeks to translate Ngāti Maniapoto values into restoration plans and projects.

The Maniapoto Cultural Health Framework was designed through a collaborative co-design process between scientists from NIWA (National Institute of Water and Atmospheric Research), staff at the Maniapoto Māori Trust Board (MMTB), and hapū of Ngāti Maniapoto hapū (Māori Business Owner 1 2019). The framework was, as one interviewee noted, about identifying "what matters to us" as Maniapoto and how "to get it [the awa] to a restored state" (Māori Business Owner 1 2019). Central to this was what Maniapoto considered to be the goals of restoration:

We use words like make right ... what do they [our whānau] consider to be the right state of [the awa] and some of it's not even [about] restoration. Some of them aspire for it to be better than what they've ever known it to be. (Māori Business Owner 1 2019)

The co-design process involved wānanga with different hapū throughout Maniapoto tribal boundaries and included:

whānau doing ... brainstorms ... [which involved them] literally just put[ing] it all down on the paper-what matters to you and what is the right state of that or a good state-what in your mind is good enough for 
[the awa]. It was just literally pages of writing all over it. [It was] unclear [what the NIWA scientists were] taking that away [from it] using the[ir] scientific western minds [but they] picked the things that are similar [to whanau], ... they [had] made tables, ... So they're doing the scientific stuff with our whannau's knowledge and then they come back to the whānau with what they've done and [then they asked] is this right? Does this resonate with you? Does this matter to you? ... So, it was like redesigning the [water] monitoring [sheets] to fit what our whānau wanted to know from the monitoring. ... So [NIWA scientists] added smell, because smell is important to our whānau when it comes to swimming in the water. (Māori Business Owner 1 2019)

The framework, thus, is specifically designed for the iwi and not intended to be a universal "Māori assessment framework" but specifically one that specifically caters to "what matters to the whanau", hapū and Ngāti Maniapoto iwi. It is based on their histories, their relationships with their wai (water) and awa, and their ways of doing things. Māori scientists, employed by NIWA, provided Ngāti Maniapoto with "some examples" of work they did with other whānau, hapū, and iwi around the country such as "one whānau ... doing drinking water ... then another ... just tuna”, which allowed Ngāti Maniapoto to see aspects that could be incorporated into their framework. Yet, scientists make it clear to Ngāti Maniapoto hapū and whānau involved in co-design process that they (the scientists) are "really aware of the fact that we [Māori] are all different" and even though "there is a lot of similarities between us as Māori ... iwi and hapū" hold different priorities and aspirations (Māori Business Owner 1 2019). Hāpu members who participated in the co-design workshops spoke about the experience in overwhelmingly positive terms. Dr Erica Williams, a Māori scientist employed by NIWA, singled out for repeated praise for her role in co-design process not only because of her "abundance of knowledge" and openness but also for making it explicitly clear that the framework was co-designed by Ngāti Maniapoto and was to benefit them (the whānau of Maniapoto); the framework was not the property of scientists, councils or others, and was to add in Ngāti Maniapoto efforts to enact their visions of what restoration was (Māori Business Owner 1 2019). 
The process of creating the Maniapoto Cultural Health Assessment Framework "sort of went backwards" by giving "the whānau the tools and then said how do you want to use them and why do we need to use them" (Māori Business Owner 1 2019). The first wananga was held at Kahotea marae "the whānau sat around and just did big brainstorms" to discuss all the things negatively affecting the awa. Then employees from Maniapoto Māori Trust Board (MMTB) and NIWA identified three key issues that different groups of whānau all identified in their brainstorming sessions ("drinking, swimming and tuna"). The "second wananga", held later that same year, involved whānau sitting down to consider what matters to them:

This is what an acceptable state of this [awa] is for us. Obviously, something that came through was tuna—all Māori care about tuna and kai. Having lots of tuna is important to us. Having lots of tuna to supply for the poukai [ceremonial gathering in support of Kīngitanga-the Māori king movement] for instance ... where the [Māori] king goes around to all [the] different mare. So, for some marae that really support the Kingitanga [the Māori King], ... it's important to have tuna at that time of year... It's not just about having heaps ... of tuna so we can eat them all the time, there's actually a cultural significance to why we need this at this time of year. So that's what we've been working on [how to restore tuna numbers] this year. (Māori Business Owner 1 2019)

However, some important issues identified by whānau were not included within the framework. For instance, Rereahu (hapū of Ngāti Maniapoto) wanted to include "birds ... everything really ... the whole habitat" not just the water and the tuna (freshwater eels). Likewise, many whānau and hapū wanted sites of cultural significance (wāhi tapu) included in the framework (Māori Business Owner 1 2019). However, the staff from MMTB and NIWA who co-designed project came to the joint decision that the inclusion of sites of significance would be beyond the scope of the cultural assessment framework and it would be better to concentrate first on the restoration of rivers and wetlands; restoration works include those that aim to replant native trees in areas cleared in the late nineteenth and early twentieth centuries (see Figs. 9.1, 9.2, and 9.3). 




Fig. 9.1 Area of Te Rohe Potāe cleared of forest in 1911. (Source: AWNS 19110907 3 2, Auckland City Libraries, Auckland, New Zealand)

It would require an entirely new framework for sites of cultural significance that would require tools that allowed for historical investigations as well as ways to assess the wairua (spiritual integrity) of wāhi tapu (something not measurable by scientific studies) (Māori Business Owner $12019)$.

Representatives from different hapū are now using the framework throughout Ngāti Maniapoto rohe, some of whom spoke about their experiences using the framework.

The realities of implementing the framework involved trying to translate the theory into practices (Iwi Rep 6 2020). Some groups were in the process of identifying sites and "doing those measurements" as well as starting work to clean-up "their oxbows" (crescent-shaped lakes that lie alongside a river). Others were seeking to address invasive species along the riverbanks and river channels (Iwi Rep 4 2020). 




Fig. 9.2 Pākehā farming household standing beside an unnamed tributary of the Waipā River in 1901. Note the absence of vegetation due to deliberate actions to log and burn the Indigenous flora to be replaced by pastures. (Source: AWNS 190104194 3, Auckland City Libraries, Auckland, New Zealand)

\section{Defining Restoration}

One Ngāti Māniapoto interviewee wanted, through his restoration work, to return the Waipā River to "the point of where it was ... a beautiful freshwater [system] with an abundance of native species". These actions should, he hopes, contribute positively to the wellbeing of his whānau, hāpu and iwi:

So when you're thinking of restoration you're thinking about-so some of our whānau-and restoration is in their mind is getting it back to what they had as [children] because they're older and then their kids can't have that [same experiences] but then some whānau are like no, it's even better than that. We want better than what we were putting up with back then. (Māori Business Owner 1 2019) 




Fig. 9.3 Restoration efforts are primarily focused on rivers, lakes, and wetlands. The photograph shows one of the numerous peak lakes, located in the middle and lower reaches of the Waipā River catchment, which volunteers have replanted with native plants and sought to reintroduce endemic fauna. (Source: Dennis Parsons (Photographer))

The word restoration "doesn't adequately cover everything that comes" up for when whānau discuss what they want. Indeed, "restoration is [about] making right" the relationship between tangata whenua and their awa. "I suppose when you translate [the phrase] make right [into te reo Māori] it's kia tika. Kia tika is a big thing for you know, [it means to] make right, make correct-kia tika. Whereas if you were going to use restoration, [the phrase you would use would] probably be whakahoki mai which is to make something good" (Māori Business Owner 12019 ). There are some slight differences in the meaning of terms between the different languages (English and Māori), paralleling the earlier differences in the Treaty/Te Tiriti, which also highlights how iwi-led restoration efforts are underpinned by Māori understandings of what restoration is and how it should be practised. 
Iwi Rep 7 considers that restoration is about "whakaoho mauri, that's to re-awaken the mauri that is in that space. Mauri is another word for being ... [and] whakaoho ... means to awaken" (Iwi Rep 7 2019b). River restoration, from this perspective, is focused on "reawaken[ing] space" which includes the wellbeing of all things. Another related word is "whakatō mauri. ... to awaken whakatō is to grow ... [so] that's to grow the mauri" of the awa (river), repo (wetlands), tuna (eels), and human beings (Iwi Rep 7 2019b). Her approach to restoration is "very holistic" and she is "thankful for the likes of NIWA" for allowing her the opportunity to be involved in a co-design process that incorporates both mātauranga Māori and western scientific knowledge (Iwi Rep 7 2019b). By being able to work with scientists as well as mātauranga Māori experts, she and other iwi representatives employed as restoration practitioners are able to maintain a balance and draw on the best of both worlds ( $\mathrm{Te}$ Ao Māori and Te Ao Pākehā).

[W] hat I just said was, we need to hold onto what our tūpuna had spoken about, in terms of looking after the awa, because if the awa is paru, then our people are not okay. That's what's going to bring wellbeing to our people, is when our river is clean and when our river is flowing and abundance of [kai] and when our people return back to the awa. (Iwi Rep 7 2019b)

\section{Iwi-Led Restoration Projects: Enacting Kaitiakitanga}

Five of our interviewees work for an iwi-led river restoration social enterprise and hold the official job title of "Kaitiaki" and are restoration practitioners who are involved in growing plants used in restoration works (Kaitiaki 1 2020; Kaitiaki 2 2020; Kaitiaki 3 2020; Kaitiaki 4 2020; Kaitiaki 5 2020). All are Mãori wahine (women) narrate their experiences raising seeds, growing plants, and planting them as alike to motherhood; three of whom are Ngāti Maniapoto, and two are from different iwi but whose partners and children whakapapa to Ngāti Maniapoto. "We are mothers to every plant in this nursery", Kaitiaki 2 muses (Kaitiaki 2 2020). A view supported by her colleague, Kaitiaki 1 "I have 408,000 
children. That's how many plants we've got on [growing]", which is framed in terms of aroha (love) and koha (gifts) to Papa-tū-ā-nuku (see Fig. 9.4) (Kaitiaki 1 2020). They raise the question: "If we aren't kaitiaki, who's going to be? Who's going to fix it? Even just a little step like this [raising plants] can make a huge difference and keep growing". The noted that for them being a paid Kaitiaki did not mean that they felt their work (as environmental guardians) stopped at the end of their working hours. Instead, their paid work made them realise that kaitiaki is a way of life: "Going home as kaitiaki, eating breakfast as kaitiaki, taking a shit as kaitiaki. All of the above kaitiaki” (Kaitiaki 4 2020). As Kaitiaki 5 similarly argues: "You're kaitiaki here, and you're kaitiaki at home ... [While we are] paid for the work, but that's not the driving cause [for doing] the work" (Kaitiaki 5 2020). Instead, the driver, she maintains, is on the responsibilities to one's kin, including future generations. "There's going to be something done [to address the environmental problems] so that we leave something behind for our children, and our children's children" (Kaitiaki 5 2020). The intergenerational dimension of river restoration is key to how they conceptualised not only restoration but also environmental justice. Issues of climate change, biodiversity loss, environmental degradation, and pollution all bring attention to the longer-term future, and questions about time and intergenerational responsibilities, and river restoration practitioners frame their work in terms of their intergenerational obligations to their atua (gods), tūpuna (ancestors), and their kin (both human and more-than-human, past, living and future generations), which includes the rivers and lands in which they live and work.

As we demonstrated in previous chapters, Ngāti Maniapoto like other iwi were unable to practice kaitiakitanga over their rohe for generations as a consequence of settler-colonialism. Yet, the injustices against Indigenous peoples were not just confined to acts of violence and dispossession, but also policies and strategies that sought to exclude and marginalise Māori knowledge and values. As a result of settler-colonial encroachment of their rohe, being Maniapoto (or Māori, or Indigenous) today means constantly engaging in a struggle to reclaim, re-know, and reassert one's identity and one's "relational, place-based existence by challenging the ongoing, destructive forces of colonization" (Corntassel and Bryce 2011, p. 152). One kaitiaki recalls how she: 




Fig. 9.4 Plants growing in the Pūniu River Care nursery. (Source: Melanie MayallNahi (Photographer)) 
grew up around here and grew up in the [Puniu] river but when I ... started schooling away from here [at] Te Awamutu Intermediate and then going on to high school, [I] spent less time around [the river and] Spent less time connected. ... I'm a little bit tainted by ... Pākehā ... schooling. Like from intermediate onwards I was total immersion in English... For me, ... [a Māori] understanding [of the world is] like a different mind state from what [is taught within the mainstream education system] ... Usually, people follow the pathway of school and then either work or university if you decide to do that. But not a lot of focus [within the education system is] on the environment and protecting your whenua [land]. (Kaitiaki 32020 )

In her role as a Māori restoration practitioner came to the realisation that she had learnt a great deal outside of formal (Pākehā) education, particularly as a child with her whanau on the marae (tribal meeting house) and in her interactions with her awa, and that this knowledge was not subordinate to that of Te Ao Pākehā. The settler-colonial logic was premised on violence (to humans and ecosystems), dispossession, and in some instances both "genocide and ecocide". From the perspective of difference Indigenous peoples around the globe, the loss of species was (and is still) the loss of kin, of culture, of knowledge, of relationships, and of modes of living. In the present-day Indigenous people express feelings of shame that they cannot speak their own language (Te Reo Māori), that they do not know their own knowledge (mātauranga) and laws (tikanga), and cannot employ the practices their ancestors used to maintain safe and sustainable environments. Indeed, in Australia and North America, many Indigenous peoples report being groups are forced to adopt (and adapt) the Indigenous knowledges of other peoples because of the scale of loss associated with "genocide and ecocide" (involving the killing of entire tribal groups, the forced removal of Indigenous peoples to government institutions, missions, and reservations, and policies of biological and cultural assimilation) (Barta 2008; Campbell 2007; Ellinghaus 2009; Kelm 1999; Parsons 2010; Rose 2004, p. 35). In these instances, ecological restoration projects can provide an avenue by which Indigenous people can acknowledge their losses, feelings of shame for being somehow 'not authentically Indigenous' (with many Māori referring to themselves as 'potatoes' - brown on the outside and white on the inside) (Bell 2014; 
Bird 1999; Corntassel and Bryce 2011; Kukutai 2013; McCormack 2012; Wanhalla 2015).

As Mohawk scholar Gerald Taiaiake Alfred writes "colonialism is best conceptualized as an irresistible outcome of a multigenerational and multifaceted process of forced dispossession and attempted acculturation-a disconnection from land, culture, and community-that has resulted in political chaos and social discord" within Indigenous communities and the collective dependency on the settler-state (Alfred 2009, p. 56). Yet, in the small acts of restoring a section of a riverbank or wetland interviewees spoke they formed (revived, restored) connections with their awa, whenua, and other more-than-human kin and in doing so revitalised their own confidence in themselves (as individuals and members of their iwi). Others spoke of feeling "proud about" their work as an official job title as 'Kaitiaki' (who are paid to undertake the practices of kaitiakitanga) and allowed them to reconnect with their own whakapapa, histories, and knowledge (irrespective of what hapū or iwi they belonged to). The physical actions of growing and planting, of removing weeds and sowing seeds helped them rebuilt the relationships (with one another, their ancestors, and the non-human worlds) that were/are disrupted by colonialism.

The practices of tending to a plant, replanting a riverbank, and restoring a wetland, also allowed for restoration practitioners to maintain and enhance their connections to their ancestors, their knowledge, and their ethics (centred on their tikanga). The Ngāti Maniapoto elders, one Kaitiaki noted, always acknowledge the shared histories and ongoing relationships between her iwi and Ngāti Maniapoto, which included her "great ... grandfather [who] came here [to the Waikato Region] and fought for Maniapoto" during the Waikato Wars (1863-1864). Such recognition of inter- and intra-iwi connections, stories and histories (of reciprocity between groups, of resistance to colonial oppression, and of cultural continuance) was situated at the heart of individuals' accounts of why restoration projects were positive (not a "cultural" benefit that was secondary to the ecological benefits of restoration, inter-personal and inter-species relationships were situated at the heart of restoration). Those Māori employed within Ngāti Maniapoto-led restoration projects, but whose whakapapa was to other iwi, felt their efforts to restore the Waipā 
awa (the ancestor of Ngāti Maniapoto) were not only appreciated by Ngāti Maniapoto but also allowed them opportunities to learn about mātauranga and tikanga. Further, their involvement in Maniapoto-led restoration efforts meant that they sought to renew their whakapapa connections to their own whanau, hapū, iwi, and awa (Kaitiaki 1 2020). As one Kaitiaki states: "I feel like [the work has] given me the tools so that I can be confident about my own pa. And [sing the] karanga. ${ }^{1}$ Get up and do my pepeha"” (Kaitiaki 2 2020).

One of our interviewees, who is involved in the co-governance and co-management of the Waipā River, described how his professional work is indelibly shaped by his identity as Ngāti Maniapoto and his iwi's history (Iwi Rep 5 2019, p. 5). In particular, he cited the importance of cultural continuation and resilience of his iwi (Ngāti Maniapoto) in the face of multiple social and environmental injustices. He recounted the history of how his tūpuna (ancestors), after the 1863-1864 Waikato War, were marginalised and experienced ongoing physical and emotional traumas as a consequence of colonial violence (to people, land, water, and biota); but they were able to survive through a commitment to unity and collective action (kotahitanga), which was underpinned by the remembering and enacting the principles and values "brought over from Hawaiki" to Aotearoa by their ancestors (Iwi Rep 5 2019). In the presentday, the efforts of Ngāti Maniapoto to enhance the health of the Waipā River is narrated by these same principles. Most notably, the principle of "wairua" (spiritual integrity) which is:

really about identity and not forgetting that we are mana atua [sacred spiritual power from the gods], mana tangata [power of the people] and we should all remember ... the stories of how we as an iwi survive and ... we have a whakapapa directly to those tūpuna [ancestors] that were there, so we are the generations that they ensured our survival. (Iwi Rep 5 2019)

\footnotetext{
${ }^{1} \mathrm{~A}$ karanga is part of the cultural protocol of a powhiri (welcome ceremony). Karanga involve the exchange of calls between senior women; either to welcome (if hosts) their visitors or to acknowledge their hosts (if visitors) onto a marae (the meeting place of a hapū).

${ }^{2} \mathrm{~A}$ pepeha is an introductory story in which a person introduces themselves through discussing places and people, including one's whakapapa.
} 
Even for those Māori who do not whakapapa to them Waipā River or its tributaries but instead married into the Ngāti Maniapoto iwi, they still considered themselves to be guardians (kaitiaki) of Waipā and Pūniu awa because of their responsibilities to care for their children and grandchildren. The water is the lifeblood of their Ngāti Maniapoto children and so they take the role of kaitiaki seriously:

we're the guardians of Pūniu awa. We're trying to restore the water. Replenish and get it back to what it used to be. And that's what a kaitiaki is to me, a guardian. It's someone who looks after something or someone. Or anything. My children whakapapa back to the Pūniu. That's their awa and I couldn't love my job anymore. I'm doing this for my kids, and for my partner and all of his family. They're so proud of us [river restoration practitioners] and our mahi [our work]. (Kaitiaki 1 2020)

Restoration practices are also about re-establishing relationships between Māori (as individuals and members of whanau, hapū, and iwi) and Papa-tū-ā-nuku (Earth Mother), which were disrupted by settler-colonialism:

You know it's so deep, so much deeper than just planting plants. And putting them out on the when. It's like acknowledging Papa-tū-à-nuku, being one with her. Cleaning her [the Pūniu River's] waterways. Not just for her, but for our children to come, for generations to come after that. (Kaitiaki 2 2020)

These duties of care go beyond cost-benefit analysis, scientific studies, and accounts of the present-day or near-future and encompasses longer time frames and infinite future generations.

Restoration projects are situated as part of wider efforts by iwi, hapū, whānau, and other groups to maintain and strength Māori culture, knowledge and tikanga, including the Māori language (Te Reo Māori), the identities and practices of iwi. As Cherokee scholar Clint Carroll writes, that Cherokee cultural revitalisation efforts are a crucial step in creating "sovereign landscapes", which he defines as "spaces where environmental governance and management take place on Indigenous terms 
and in Indigenous ways, however complex and multifaceted they may be" (Carroll 2015, p. 33). Critical to producing sovereign landscapes, Carroll argues, that this involves "fashioning modes of environmental governance" that are more in line with Indigenous values and perspectives towards more-than-human worlds (Carroll 2015, p. 33). To facilitate this, many iwi representatives suggested that Ngāti Maniapoto's cogovernance, co-management, and restoration projects efforts need to shift focus from one based of Western framings of rights to one focused on responsibilities; the intergenerational responsibilities to ensure that health and wellbeing of future generations, including the capacities of the next generations to exercise rangatiratanga (authority and power) and practice kaitiakitanga according to the tikanga of Maniapoto. Interviewees from Ngāti Maniapoto repeatedly articulated how their involvement in ecological restoration projects and river co-management planning were motivated by their multiple responsibilities to their rohe, including included land, water, biota, and past/present/future generations.

Such a perspective of intergenerational environmental justice (which includes for both human and more-than-human communities) is similarly observed in other Indigenous societies (Alfred 2015; Leonard et al. 2013; Norgaard et al. 2018; Nursey-Bray 2016; Nursey-Bray and Palmer 2018; Turner and Clifton 2009; Winter 2018). The importance of thinking "seven generations into the future" is, for instance, the key principle guiding Haudenosaunee Nations (one of the Indigenous peoples of the US) sustainable stewardship of their lands and waters (Brookshire and Kaza 2013; King 2006, p. 449). Many members of Indigenous Karuk people express concern about declining numbers of salmon in their rivers and how climate change is likely to make it even more difficult for future generations to engage in salmon fishing, which is not an important source of healthy protein for Karuk families but also is considered an essential part of their identity as Karuk (such concerns are similarly expressed by different Indigenous peoples within the settler-states of Canada and the United States in regard to salmon and other fish and fauna species) (Denny and Fanning 2016; Diver 2012; Norgaard et al. 2018; Todd 2014). In the Waipā context, Ngāti Maniapoto articulate their anxieties that already diminished and degraded stocks of native flora and fauna will further decline in the future, and that future generations would no 
longer be able to harvest from their mahinga kai (food gathering sites). However, they also articulated their hopes that restoration projects would help to improve the quality and quantity of freshwater biota; and in doing so heal the interwoven physical and spiritual traumas experienced on Ngāti Maniapoto as a collective group (iwi, hapū, whānau) but also those endured by individuals, and the traumas infected by colonialism and degradation on their more-than-than human kin (including the river and water).

An unhealthy river not only causes aquatic flora and fauna to be unwell but also causes suffering for tangata whenua who are kin to the river and the more-than-human entities who dwell within waters of the river and its tributaries. As Panelli and Tipa, writing in the context of Māori wellbeing, demonstrate notions of reciprocity and the interconnectivity of individuals and wider social, ecological, and metaphysical entities means that the health and wellbeing of individuals cannot be simply be separated from the socio-cultural units in which they live (Durie 1998; Panelli and Tipa 2007). Like many other Indigenous cultures, the wellbeing of iwi Māori (referring to people who identify with a specific tribal group) is predicated on consideration of both individual and collective experiences, which includes self, whānau, hapū and iwi (Panelli and Tipa 2007). Accordingly, an understanding the Ngāti Maniapoto health and wellbeing is situated within the health and wellbeing of their rohe, and associated resources (Durie 1998; Panelli and Tipa 2007; Tipa and Teirney 2006). Stories of the healing qualities of "pristine waters" of the Waipā waterscapes (it's rivers, streams, wetlands, lakes and springs) are recounted by current generations of Ngāti Maniapoto. So too do they tell the stories of their ancestors watching on, protesting against, and sometimes participating in actions that radically changed the taiao (environment) and resulted in its "the mauri (life force) of the river [being] degraded" (Iwi Rep 5 2019). As a young person, one of our interviewees recalled how his wife told him: "well once the river's healed our people will be healed and that will set the way forward. That will help us" (Iwi Rep 5 2019). At the time, he dismissed what his wife told him, thinking to himself "that's just bullshit basically"; but now "I've learnt [actually] working in this space [of river restoration], everything's connected" (Iwi Rep 5 2019). As he now realises: "It's about wisdom really and it's very true. If you're drinking 
polluted water, or water that's been treated with chemicals, you're not going to be 100 per cent right you know?" Indeed, the process of establishing co-management arrangements, contributing to river planning documents, and engaging in restoration work, many within Maniapoto report renewed appreciation for their mātauranga. As we discussed earlier in Chap. 2, mātauranga is premised on a holistic way of thinking wherein human and more-than-human are constituted and co-constituted through kinship relationships (whakapapa) that are place-based and intergenerational.

For Ngāti Maniapoto, like their neighbours Waikato-Tainui (whose rohe is to the north and includes the lower and middle reaches of the Waipā River as well as the Waikato River), when people are unwell, they traditionally would go to the awa to sprinkle themselves and swim in the waters of the Waipā to be blessed, healed, and relax. In 2020 local Māori recount how they still go swimming in the local waterways of the Waipa and Pūniu Rivers and still anoint themselves with water to receive the blessing of their ancestors (see Fig. 9.5) (Kaitiaki 2 2020; Kaitiaki 5 2020). In the context of river restoration work, iwi representatives narrate how spiritual dimensions (the "wairua of it") underpin the work they do:

water is life ... Rivers are the blood of the land ... We get nurtured by the land and it all interconnects. We're all [are all interrelated] — life and death [are] really connected closely to us all, so if we don't stop [the destruction], if we don't look after our taiao or our waterways we will inevitably perish, or get really sick ... It's just like if we don't look after our people, ... the same thing [happens]. We just create a desperate situation. (Iwi Rep 5 2019)

Others recount how they no longer swim in the waterways due to pollution but continue to rely on the awa to maintain their physical and mental wellbeing.

I use the river to reset. Like so that's my... when the head is heavy, I come down to the river by myself. Hopefully, there's no one down here. And you know spend time by myself and think, process. (Kaitiaki 3 2020) 


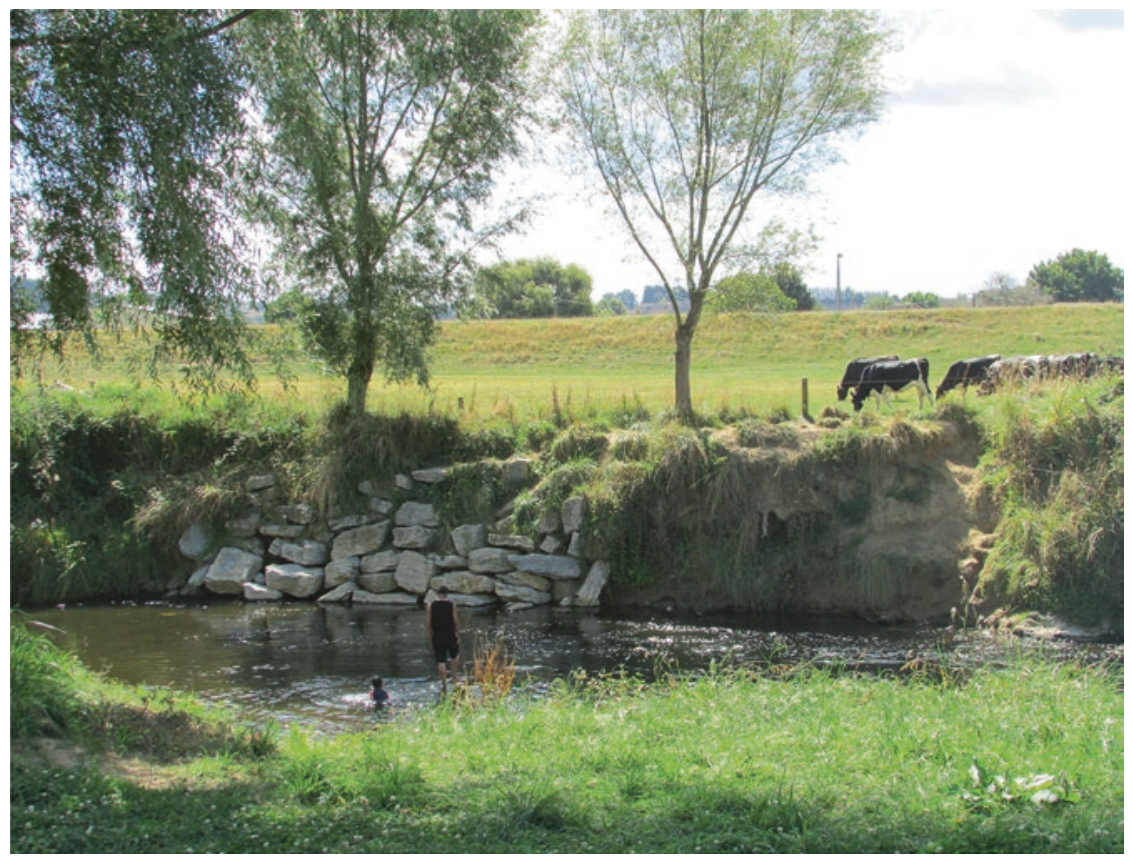

Fig. 9.5 People swimming in the Waipā River in 2019. Note this stretch of river (like much of the river catchment) still does not include any riparian plantings and cows graze right beside the river. The Waikato contains the most amount of cattle ( 1.9 million dairy cows and 480,000 beef cattle) of any region in Aotearoa, which equates to 5.11 cows per person. Unsurprisingly the Waikato region also generates the highest greenhouse gas emissions in the country chiefly as a consequence of cattle (who produce methane gas) and energy production. (Source: Karen Fisher (Photographer). (Statistics New Zealand 2020))

Some other interviewees record that they continue to swim in the waters of the Waipā and Pūniu Rivers, even though the water tastes "paru" (dirty, filthy), filled with algae, silt, and sediment. They also harvest foods (tuna and freshwater mussels), but they taste of dirt and sometimes sewage when they eat them (Kaitiaki 1 2020; Kaitiaki 2 2020; Kaitiaki 4 2020). All the iwi restoration practitioners expressed the hope that their efforts to restore the Waipā and its tributaries would ensure that their descendants would enjoy greater capacities to swim, harvest kai (food), and even drink the waters of the Waipā without fear of E.coli and other infectious diseases. 


\section{Grief and Hope}

A significant (oftentimes) unacknowledged part of restoration work involves people addressing the difficult emotions attached to recognising environmental loss and degradation. As environmental historian Lillian Pearce writes: "Those who forge strong bonds with a place open themselves up and to confronting the overwhelming realities of ecological decline, extinction and the wider impacts of climate change" (Pearce 2019 , p. 269). Pearce, writing from the perspective of Australians (most of whom were White Australians) engaging in efforts to restore their lands, acknowledges that the affective experiences of restoration work different between cultural settings. Yet, Indigenous peoples lived realities of environmental degradation and destruction (of ecocide) are not just confined just to the immediate present but instead are intergenerational and interconnected with their experiences of colonial dispossession. Indigenous peoples globally live with the legacies of environmental dispossession (the processes that reduced their abilities to access resources from their local environments) and environmental injustices that have radically affected their relationships with lands and waterways that sustained their livelihoods and social, cultural, economic, and spiritual wellbeing for generations (Tobias and Richmond 2014).

Many interviewees reflected on their own whānau (family) histories of loss (alienation from their land, language, homes, food sources, and ways of life). One Ngāti Maniapoto iwi representative recalled how his mother and whānau were made "homeless in Ōtorohanga because of the river diversion" when their land was compulsorily acquired by the local government (Waikato River Authority) under the Public Works Act as part of flood management scheme for the township instituted after a large flood event in 1958 Many Māori who lived alongside the waterways were left " $[\mathrm{h}]$ omeless, landless, resource-less, economy-less $[\mathrm{sic}]$... from the river diversion in Ōtorohanga" and many migrated away in search of work (Māori Business Owner 1 2019). The decision to divert the river part of a wider Otorohanga Flood Management Scheme that involved the re-engineering of the channels of the rivers and streams that surrounded Otorohanga, the drainage of remaining areas of wetland, the 
removal of trees along the riverbanks, and the construction of large flood levees (District Commissioner of Works 1958; McLeod 1964). All these works involved the government compulsory acquiring ("taking") of Māori land, which included whānau land as well as the area reserved as a Māori urupā (cemetery). Such actions contributed to further environmental dispossession of Ngāti Maniapoto, whereby people's homes, cultivations, wāhi tapu (sacred sites), and mahinga kai (food gathering sites) were destroyed (paralleling actions decades earlier when the wetlands were drained as discussed in Chap. 3).

Such historic experiences of environmental dispossession continued to impact people's day to day lives in the 2010s, with interviewees talking about how they were not able to harvest the resources and prepare the foods that their ancestors did (Māori Business Owner 1 2019). They spoke of their own lives (childhood and adulthood) as well as those of their parents and previous generations (grandparents, great-grandparents, and so on) were all connected with the taiao and how cumulative impacts slowly eroded their relationships with the wai and disrupted the mauri and wairua (spiritual integrity) of all Ngāti Maniapoto kin (human and more-than-human). As a child, one interviewee, recalls: "we could walk along the river. You could head the birds. You could hear the river...you could feel the wairua in the river. Now it's just a trickle", but before (before drainage, river realignment, and flood levees) the water used to rush down it (Iwi Rep 4 2020). The interviewee also describes the smell of the river, and how smell is an indicator of health. If the water smelt a particular way people knew it was healthy and people could swim, drink, and harvest food from it, with the smell of the Waipā now described as paru and foul-smelling (an indication to iwi of its polluted status). In addition to harvesting food, water, medicines and other materials from their waterscapes, Maniapoto also used rivers and streams to preserve foods. In particular, one interviewee recalls how she and other kuia (grandmothers) used to put corn into baskets and place it in the river (attached it to poles) and leave it there, in the rushing waters, until the corn was fermented (a local delicacy which is no longer prepared or eaten) (Iwi Rep 4 2020). They spoke of how their ancestors used to harvest tuna from the lakes, rivers, and streams of the Waipā River catchment during the early-to-mid twentieth century using pã tuna (eel weirs), but they 
could not so not only due to the limited numbers of tuna living in the waterways but also because of drainage of wetlands (outlined in Chap. 3) and various legal restrictions placed on their abilities to access waterways and built physical structures (eel weirs) in waters that they did not possess the legal authority (under settler-state legal order) to do so; even if tikanga recognise them (Ngāti Maniapoto) as mana whenua which gave them the authority. Iwi representatives recall being able to see where they tied the hinnaki (woven basket used to catch tuna) to the bottom of the river because the water was so clear and "there were times when you could walk along [the riverbanks] and the water would shine with all the [fish]" (see Figs. 9.6 and 9.7) (Iwi Rep 4 2020). However, "doesn't do that anymore" as the water (Iwi Rep 4 2020). Indeed, as we describe in Chap. 5, the Waipā River and its tributaries and now filled with sediment, algae blooms, and pollutants from towns, factories, and farms meaning that few aquatic fauna can survive in it; its waters are heavily critiqued by scientists, iwi, and other local residents for its unappealing looks (being a murky brown with an occasional dash of green from algae) and smell (mud mixed with effluent). In the past, one interviewee recounts, the clear and "clean" waterways were filled with fish and other aquatic life (Iwi Rep 6 2020). The interviewee recalls: "[you'd] put a hīnaki in [the river and] it would come out full [with tuna] for any gatherings". One could "feed the [entire] whānau" (family) and "all the marae" (hapūbased meeting complex) with tuna caught in a single hīnaki. However, in the present-day "you can't do it, ... I think the last time we put a hinnaki in would have been probably four, five years ago and it was in there for a week. We were lucky to get two" (Iwi Rep 4 2020).

Hobb wrote applied the psychological concept of "stages of grief" (denial, anger, bargaining, depression and acceptance) to people's relationships with environmental degradation and changes (Hobbs 2013). Yet, unlike the death of a person, the losses of environments (of animals, plants, waterways) are uncertain, chronic, and diffuse. The practical and metaphorical lessons of grieving, Hobbs and other scholars suggest are helpful to extend to think about how different cultures respond to environmental changes (Cunsolo and Ellis 2018; Dawson 2015; Hobbs 2013; Pearce 2019). Although Hobbs principally examines the loss of ecosystems and species, research by Pearce demonstrates that "loss can 


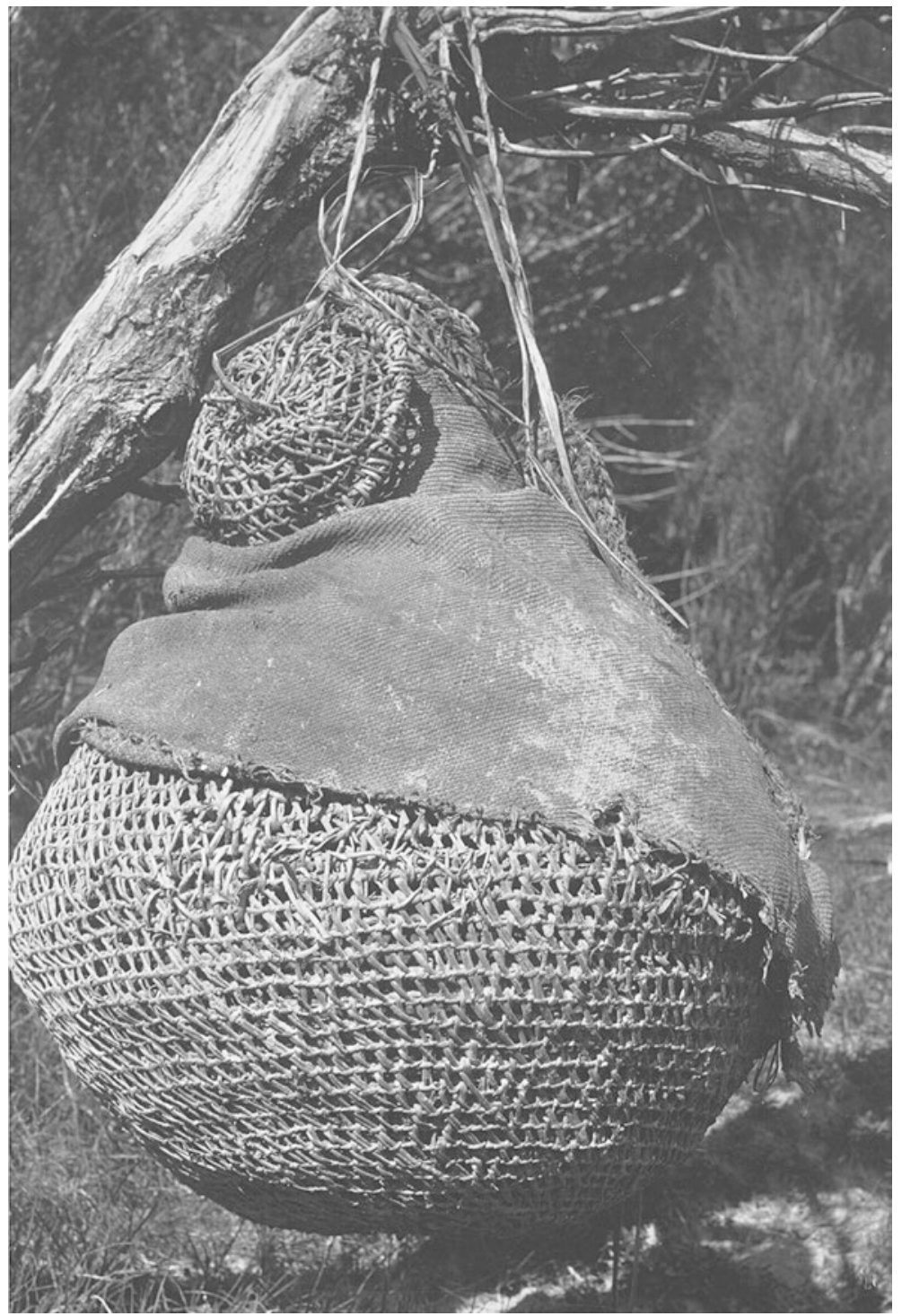

Fig. 9.6 Photograph of one type of hīnaki. (Source: McDonald, James Ingram, 1865-1935. Photographs. Ref/ PA1-q-257-71-1. Alexander Turnbull Library, Wellington, New Zealand) 




Fig. 9.7 Another type of hīnaki, Whanganui River area (Located south of the Waipā River). (Source: McDonald, James Ingram, 1865-1935. Photographs. Ref/ PA1-q-257-72-2. Alexander Turnbull Library, Wellington, New Zealand)

come in much more complex and connected ways, and the communal experience of loss can resurrect a more ethical, relational and collective grief” (Pearce 2019, p. 261). Pearce describes her own experiences of seeing images of environmental destruction of the forests in Tasmania (Australia) where she once lived (as a consequence of wildfire) and the sobering realisation that the landscapes she took bushwalks through as a young adult would not be the one's her daughter encountered. Similarly, van Dooren examines how the experience of mourning can help people more conscious of their relationships with more-than-humans and inspire a caring responsibility (van Dooren 2014). Van Dooren encourages making space for reflection, more and actions, likewise Pearce and Hobbs suggest that the grieving process is a fundamental part of restoration works as a way to "collectively grieve the possibilities and relationships 
and ways of being in the world that go along with species and ways of life" (van Dooren 2014; Hobbs 2013; Pearce 2019, p. 263). Yet, all of these discussions of grief and loss (sometimes referred to in terms solastalgia) are very much framed from the vantage point of Euro-Western intellectual traditions, cultures, and histories.

Many Euro-Western scholars, as we discuss in Chap. 1, situate the Anthropocene as a recent arrival (mid-twentieth century) that is radically changing environments and in doing so placing their ontological security and their homes on shaking ground (Steffen et al. 2011, 2015). However, for Indigenous peoples and Indigenous allies start of the Anthropocene begun hundreds of years earlier when European colonisation commenced, and their homelands were invaded. Indigenous peoples are not just suddenly recognising the environmental changes are occurring (as we highlight in Chaps. 3, 4, and 5 settler-colonialism in Aotearoa involved deliberate actions to alter Māori landscapes and waterscapes since the 1840s radically) nor are they just experiencing loss and grief (Davis and Todd 2017; Whyte 2017). Indigenous peoples, as Whyte argues, already know what it feels like to experience loss of relationships, ways of life, and worlds, they continue to live with the loss and grief associated caused by (and still causing) colonialism (and the multiple environmental injustices) (Whyte 2017, 2018). Moreover, unlike Western ontologies, Indigenous ontologies (like Te Ao Māori) are already premised on reciprocal relationships between human and more-than humans, kinship, and intergenerational responsibilities of care, and so experiences of the earthshattering traumas and losses associated colonisation were (and are) not needed for Indigenous peoples to adopt a "position of ontological plurality that takes seriously inter-species relationships" which Western environmental management and restoration practitioners are encouraged to embrace (Pearce 2019, p. 269). Principles of caring and responsibilities for the wellbeing of other species are already woven into mātauranga Māori and tikanga (as we highlight in Chaps. 2 and 4), and for Māori restoration practitioners in the Waipā restoration work was not about only about grief but also about hope.

Hope emerges from amidst the eco-violence, uncertainty, and losses of the Anthropocene, when Indigenous responsibilities (intergenerational environmental justice embracing both human and more-than-humans) 
are not only recognised but also transformed into actions. It involves the reciprocal processes of healing relationships between people and rivers through changing how rivers are governed, management, and interacted with, which involves shifting away from the ontological and epistemological privileging of Western cultures and knowledges (Fox et al. 2017; Te Aho 2010, 2019). The process and outcomes of restoration efforts, Māori restoration practitioners maintained, should be directed at the process of healing (the waters, biota, and themselves) because "Healthy waters [means] healthy people" (Kaitiaki 5 2020).

Iwi representatives who worked in restoration projects drew direct links between their own engagement in restoration efforts and what they deemed to be the ultimate goal of restoration (and what would be considered successful restoration): the need to improve, enhance and maintain the mauri of wai, whenua (land), and taonga (treasures) for future generations. Those taonga included the birds who live in native forest lining the rivers as well as within the wetlands. As one interviewee recalls:

When we were small, you could walk along [the riverbank] and hear the birds, so we have hope with the, some of the native plants that we've put back along the river, that all those birds would come back. (Iwi Rep 4 2020)

Maniapoto Māori Trust Board wants to conduct a count of kererū (New Zealand Pigeon Hemiphaga novaeseelandiae) so that the iwi has a rough idea of the number and distribution of kererū in their rohe (Baranyovits 2017; Bell 1996; Schotborgh 2005). Kereū are considered by Ngāti Maniapoto (and many other iwi) to be a taonga (formerly eaten by Māori but now protected under law), whereas ecologists refer to them as a keystone species. Kererū are significant for the survival of a large number of forest species and are the major or only seed dispersers for more than 60 tree and shrub species in Aotearoa (Bell 1996; Carpenter 2019). Accordingly, many iwi restoration practitioners would like to expand their restoration efforts from riparian areas and wetlands to encompass the whenua more and include creating more habitat for kererū.

Future restoration efforts iwi participants also spoke about included those aimed at providing more suitable habitats for tuna. One proposed idea is the creation of "tuna hotels", which is already used by another iwi, 
and involves the introduction of "white plastic pipes" into riverbanks. The tuna hotels are "put ... in the side of a fast-flowing awa so that tuna can go in there and rest" (Iwi Rep 6 2020). Along similar lines, the Waipā Rerenoa Restoration Project is "looking at putting rock structures in, just to slow the awa down" so that "the tuna can hide behind th[e] rock structures" (Iwi Rep 4 2020). At the moment, the water in the awa as it runs through the township of Otorohanga runs too swiftly for native aquatic fauna, with straight sides, and no vegetation. As a consequence of the ongoing engineering works undertaken at Otorohanga, to drain the wetlands and mitigate flood risk (discussed earlier in Chap. 4), the Waipā "River has sped up a lot", and so there are no longer any "resting spots, even for fish" (Iwi Rep 6 2020). Thus, the restoration works planned by hapū involve actions "to slow the river down and to have areas for the habitats [of] fish [and] tuna" (Iwi Rep 4 2020). The conceptualisation of restoration work contributing positively, even if only incrementally, to future generations motivated individuals and collectives engagement in existing and support for larger-scale restoration projects within their rohe.

Hope lies in the realms of imagining and dreaming, language and discussing, and translating the abstract into the practical (be it within one's home, backyard, riverbank, wetland, forest, rohe, marae, office or community). Restoration is about hope. It is about acknowledging the longsilenced histories of Indigenous environmental dispossession and ecological destruction, and in doing so, challenging the curated settlercolonies histories peaceful settlement and nation-building. By recognising (in-laws, policies, and plans) the coupled impacts of colonialism on people and ecosystems, the new co-governance and co-management arrangements are facilitating hopefulness amongst Ngāti Maniapoto. Especially amongst those working to enact restoration on the ground, and despite the issues, individuals and groups are facing with lack of sufficient funding to support their restoration efforts they express a renewed sense of hope for the future. Iwi Representative 7 talked about her huge optimism about the future after talking to young people and seeing their "potential. I see this light ... the kids that are a blank canvas. Some of our rangatahi [younger generations] I see put up some beautiful posts [on Facebook] and I think you're in a good space" (Iwi Rep 7 2019a). Indeed, many spoke of their hope that future generations will be willing to 
continue to step up and embrace Maniapoto ways of being (tikanga and mātauranga) and adapt to changing situations. Ngāti Maniapoto already possess long, rich histories of stepping up, be it by taking leadership roles (within Kīngitanga and the creation of Rohe Pōtae), or resisting colonial intrusions (during the Waikato Wars, seeking to maintain rangatiratanga within Rohe Pōtae) and launching petitions and legal campaigns in the face of injustices. Restoration practices are just another way Ngāti Maniapoto are stepping up and taking actions to address environmental degradation and achieve more justice futures grounded in their mātauranga (knowledge), tikanga (laws), mana (power and sovereignty), and rangatiratanga (authority and power). The act of stepping into the muddy, polluted waters of the Waipā and Pūniu to plant raupo, standing amongst seemingly impregnatable thorn-covered gorse bushes (Ulex europaeus) and valiantly to remove them as one's arms become covered in scratches, may not seem like being part of any sort of healing process. However, small scale restoration works are grounded expressions of hope, of healing, and of authority, which are situated in particular places, histories, cultures, and relationships. Hope, environmental historian Alison Pouliot writes:

is one of those intangible things that begs for logic and for something less tangible; something based in emotions and belief. Hope arises from the capacity to feel and care. It relies on past experiences to project into the future. (Pouliot 2016, p. 339)

Hope comes from turning up in a cold and foggy winter's day and stands with mud coming up to one's knees to plant flax and manuka (see Figs. 9.8 and 9.9) beside Lake Ngāroto, Pūnui or Waipā Rivers (or one of the numerous lakes or waterways within the catchment). It is displaying acts of caring to others amidst all the uncertainties (of the Anthropocene, of everyday life). Every so other these practical acts of grounded hope are meet with a non-monetary gift in the form of the return of tuna swimming in a stream or the sound of a flock of kererū cooing in the trees. Every returned species, every section of whenua (land) and repo (wetland) replanted, is a promise fulfilled by kaitiaki (to themselves, their ancestors, children and grandchildren, and their kin), a reciprocal 


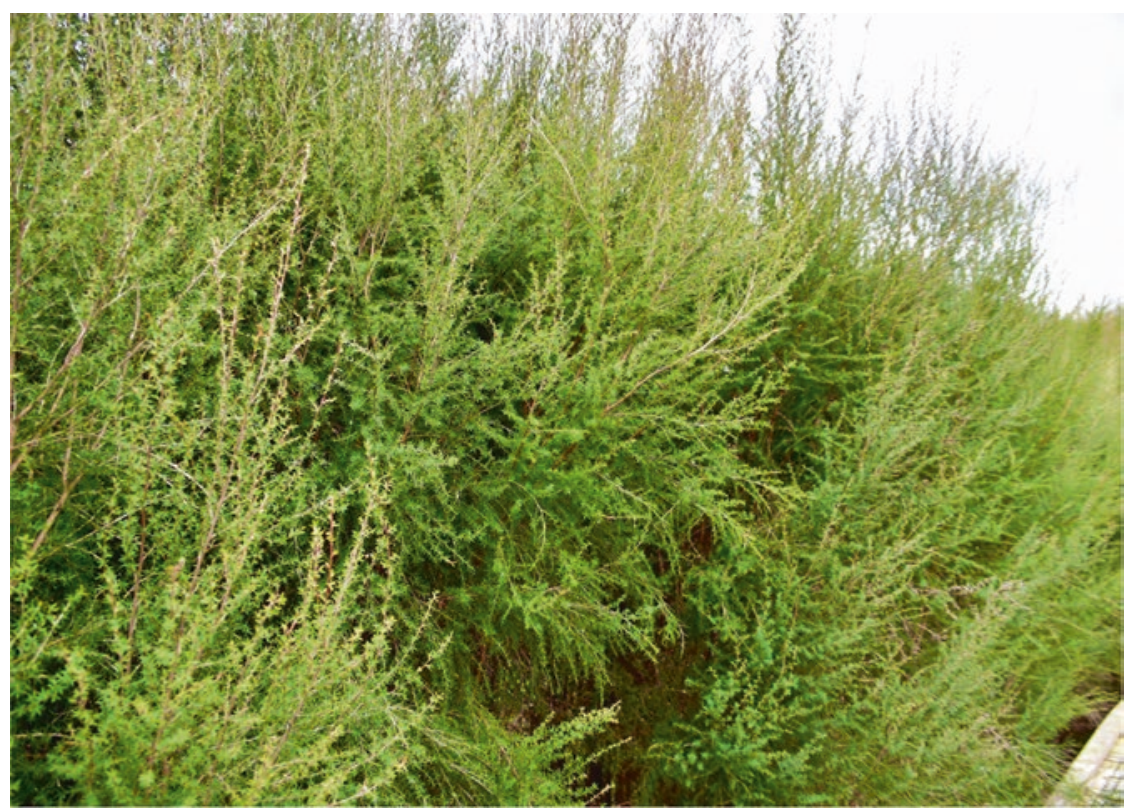

Fig. 9.8 Manuka replanted around Lake Rotopiko (one of the peat lakes within the Waipā catchment). The lake, including a small area of wetlands and forest, was restored by volunteers under the direction of the National Wetlands Trust. The restoration efforts were funded, in part, through a grant received by the WRA (through the WRCUT). (Source: Dennis Parsons (Photographer))

message that communicates both the benefits and responsibilities of environmental stewardship for future generations.

Yet, the hope provided by river restoration is (and needs to be) realistic and based on the reality of local contexts and conditions. Restoration, therefore, involves the revival or creation of relationships between people and taiao (environment) — their landscapes and waterscapes_- which are based on knowledge of how environmental conditions are constantly changing, and so too social conditions are changing. One iwi representative noted that the iwi needed to create more opportunities within its various institutions (be they iwi-, hapū-, and co-led) such as the MMTB and WRA so that Maniapoto youth are mentored and trained so that they can take up leadership roles within river governance, management and restoration projects (Iwi Rep 7 2019a). The passing of experiential 


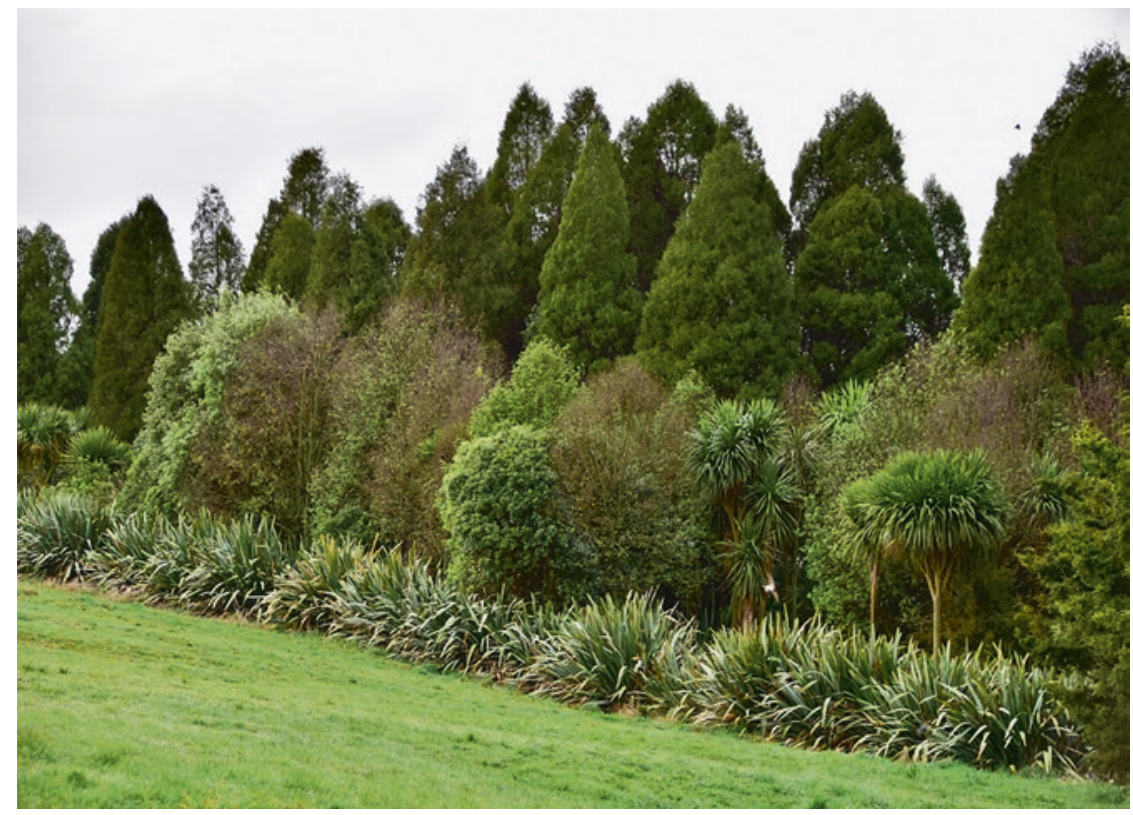

Fig. 9.9 Established trees and shrubs at a wetland restoration project (Lake Rotopiko) within the Waipā River catchment. This photograph shows newly established plantings of tī kōuka (cabbage trees or Cordyline australis) and Harakeke (flax or Phormium tenax) as well as older trees (remnant stands of Dacrycarpus dacrydioides or kahikatea) that escaped being felled or burnt during the 1860s-1960s efforts of landowners' and governments to removal all indigenous vegetation from the catchment. (Source: Dennis Parsons (Photographer))

knowledge, including of restoration, to younger generations within the iwi is considered a critical part of the cultural continuance (its mana) and wellbeing of both Maniapoto (iwi/hapū/whānau) and its taiao (environment). The educational component is, many iwi representatives note, currently missing from the ways in which environmental governance, management, and restoration is being framed within Maniapoto's own institutions (as well as within its various collaborations with other iwi, councils and scientific bodies). An iwi representative noted the iwi needed to develop a clearer "succession plan" so that younger generations within the iwi, hapū and whānau could learn from the older generations about how to care for the awa, the whanau, and each other. A successive plan would mean that when individuals with particular knowledge and skills 
departed Maniapoto (due to death, retirement, or changing jobs), their knowledge was passed onto the next generation (Iwi Rep 7 2019a). Iwi participants also emphasised the need to educate younger generations in mātauranga, tikanga, kaitiakitanga as well as western knowledge so that youth are fully equipped to walk between and exist in multiple worlds (Māori and Pākehā). Since restoration efforts are expected to be ongoing (stretching forward for at least the next half-century) iwi interviewees emphasised the importance of future generations taking up the mandate of protecting the awa (kaitiakitanga). By understanding the overlapping and ongoing processes of environmental degradation, restoration, and regeneration, we argue, one starts to appreciate and envision how to implement more meaningful, sustainable, and substantive decolonising practices. Future generations of Maniapoto (as well as other iwi and nonMāori) will map out their own pathways for restoration, which address their needs, concerns and aspirations (Corntassel and Bryce 2011, pp. 160-161). Decolonisation does not just involve legal and political performances (of Treaty settlements, co-governance arrangements, of legal personhood) aimed at recognition; it also moves into the everyday realm of socio-cultural and ecological practices where Mãori plant trees on the side of a riverbank, count birds in the trees, and make an endless submission to councils demanding actions to address water pollutions. All these acts are ways Ngāti Maniapoto assert their rangatiratanga (power and authority), exercise their kaitiakitanga (environmental guardianship), and enact whanaungatanga (kinship, relationship, sense of connection gained through shared experiences and working together).

A commitment to kaitiakitanga and whanaungatanga has the possibilities to reshape and regain connections with more-than-human entities. The revitalisation of mātauranga (knowledge) and tikanga (is) is of certain importance to supporting Ngāti Maniapoto and other iwi visions of healthy spaces, beings (human and non-human), and relationships.

One iwi member, who is involved in restoration works and still harvests kai (food) from her rohe (despite her knowledge that the waters are polluted and she may become ill from consuming the good), argues that restoration is about re-establishing and maintaining her (and her wider whānau, hapū and iwi) relationships with their more-than-human kin (see Fig. 9.10). The act of being able to harvest and eat food collected 


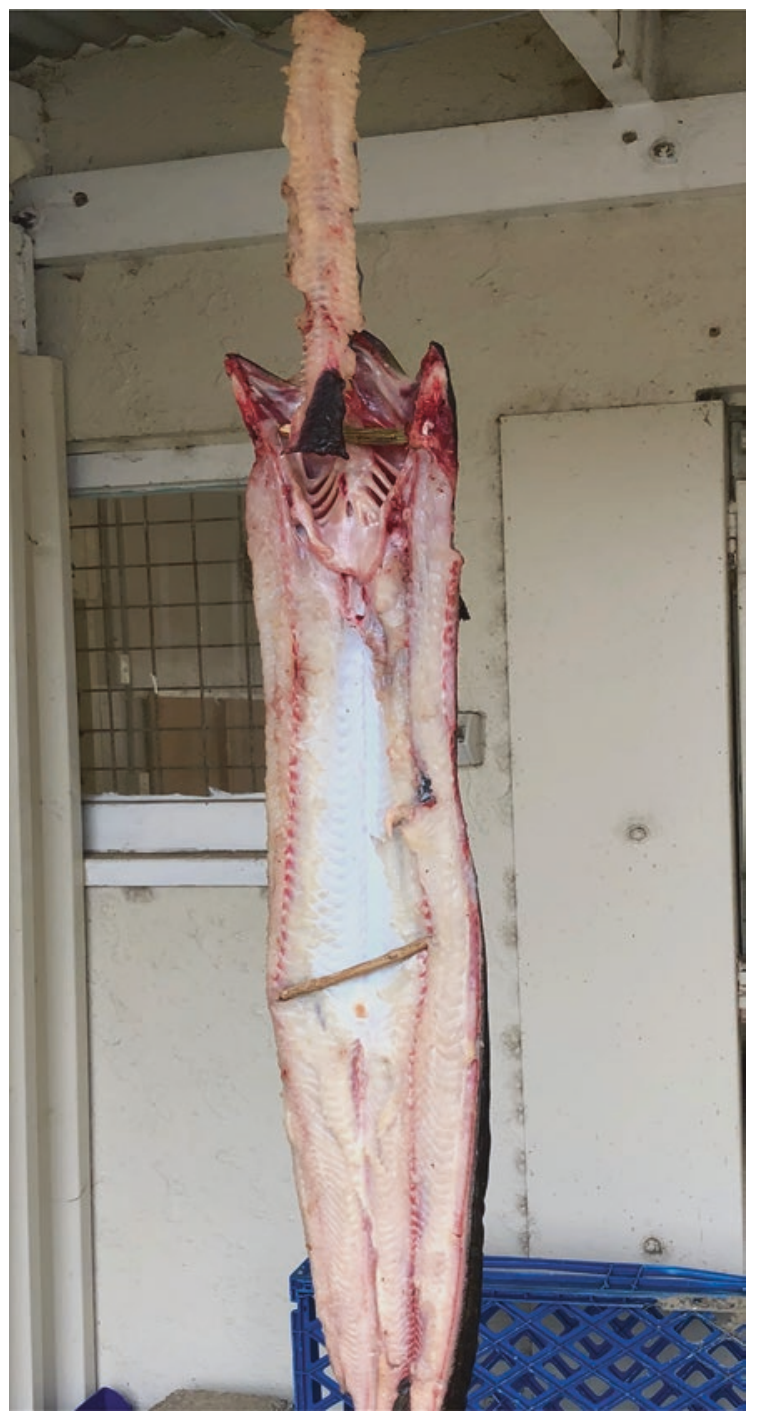

Fig. 9.10 Eel caught in the Pūnui River being prepared for cooking. (Source: Melanie Mayall-Nahi) 
from her mahinga kai (food gathering sites) is an expression of her connectivity with her ancestors and all her kin:

karakia [prayer] ... [that] addresses the kai [food] as being our tupuna [ancestors] and us having whakapapa [genealogy] to it. So, it calls the gods forth within the kai [food] and within ourselves, as being [a] relationhaving a relationship to each other through our genealogy to the gods. It calls them forth and it says, come, and be our feast with us, in this feast you are the feast. It addresses us all as the children of Ranginui and Papatūānuku. Before you eat, you — whether it's—I don't know—a leaf or somethingyou sniff whatever it is in your kai and it's symbolic of releasing the [mauri] from the kai [food] that you have gathered for it to continue. (Iwi Rep 3 2020)

The ontological and epistemological differences between Western liberal and those of Indigenous intellectual traditions, as noted previously by McGregor (2014) and Winter (2019), means that the processes of ontological and epistemological pluralism within freshwater governance, management, and restoration are fraught with ongoing obstacles. Indeed, the dominant (Pākehā-centred) settler-colonial society in Aotearoa is not always accepting of mātauranga and tikanga (at least not on the terms that Māori find acceptable). However, in order for Aotearoa to move towards more sustainable ways of interacting with water (governing, managing, restoring), it is of crucial importance that we (as academics, community members, and a nation) undertake the process of decolonising and disrupting the status quo. At the moment, we still find ourselves in the situation where water quality in Aotearoa is poor (and worsening), which is closely connected to the ever-increasing amounts of pollutants are pouring into our waterways; at the same time increasing demand for water (chiefly from irrigated agriculture) are contributing to growing water scarcity. All of which is meaning diminishing biodiversity and reducing capacities for communities to seek physical and emotional subsistence from the waters and biota of the rivers. 


\section{Conclusion}

The current situation, as we argue in previous chapters, involves tikanga (laws) being broken (tapu of waste, the kinship obligations to care for the land and water, the sustainable use of biota for future generations) without any negative consequences on the wrongdoers (settler-state). When Indigenous "laws are broken with no resource", McGregor (2014, p. 19) observes in the Canadian First Nations context, the legal order is destabilised, which in turn causes negative consequences for Indigenous peoples. In sum, the foundations of the dominant settler-colonial legal order, and the settler society itself, stands on "shaky ground due to the ongoing and often wilful ignorance" of Indigenous laws. Settler societies' efforts to reconcile Indigenous peoples (remedying injustice through legal, institutional, and financial reparations) necessitates the recognition and empowerment of Indigenous ontologies and epistemologies in ways that include more-than-human rights, responsibilities, and justice requirements (McGregor 2014, 2018). The notion that there mutual responsibilities that are shared between human and more-than-human beings (such as people holding duties of care to water and vice versus) rests at the heart of many Indigenous ontologies including Te Ao Māori. The act of planting a tree or clearing a pathway so fish can migrate up or down a river again is a practice of kaitiakitanga (as our interviewees quoted earlier in this chapter highlight), it is also an act based on the belief that they (as tangata whenua and as kaitiaki) are responsible for caring for (in this instance restoring) the river and its flora and fauna.

The dominant discourse of environmental justice typically situates responsibility for achieving justice (and addressing injustice) securely with government (that often hold an administrative responsibility towards Indigenous peoples). However, in most instances, these arrangements do not provide adequately for environmental justice (from the perspective of Indigenous peoples). Indeed, McGregor argues that if such responsibilities (for defining what justice is and how it can be achieved) remain solely within the hands of government decision-making and within Western legal systems, it is highly unlikely that Indigenous 
environmental justice will ever be secured in any meaningful and lasting manner. Indeed central and local governments in Aotearoa consistently talk about sustainability and healthy rivers, but rarely take actions that create any on-the-ground improvements that contribute to better water quality, increased biodiversity, and enhanced connectivity between tangata whenua, awa, and whenua. Indeed, relying on the settler-state and Western legal orders is unlikely to achieve environmental justice or sustainability in ways that Māori or other Indigenous peoples require. Instead, this chapter highlights how restoration efforts are an avenue by which members of Ngāti Maniapoto (as well as people from other iwi) are (in the process of) restoring the balance (between them and their more-than-human kin) and in doing so restoring just (reciprocal) relationships within their rohe. It is not a short-term process, but rather a long-term (interviewees suggest it will take anywhere between 50 to 100 years to restore their awa). Restoration is an intergenerational pathway by which individuals and groups are seeking to achieve environmental justice in their own way, using their own ways of knowing and being (outside the narrow confines of Western liberal thought premised on the division of nature from culture and the upholding of the world economic order). Such an assertion does not absolve the settler-state of Aotearoa (or other colonial governments) of all the responsibilities they currently possess with respect to environmental injustices and addressing justice, but rather that the current settler-colonial system built on capitalistic exploitation regularly shows itself as being inadequate at achieving Indigenous environmental justice (as demonstrated by the widespread Indigenous opposition to mining in Aotearoa, Australia, and Canada, pipelines in Canada and the US, hydroelectric dams in Brazil and India, to name just a few) (McGregor 2014). So it is time to consider the pluralistic nature of and practices of achieving and sustaining Indigenous environmental justice. For Ngāti Maniapoto, the small act of planting a tree, building a 'hotel' for eels in the side of a riverbank, and re-establishing their connections between themselves and their tūpuna through engaging with Te Awa o Waipā (the Waipā River), are steps towards bringing about environmental justice. 


\section{References}

Abernethy, B., \& Rutherfurd, I. D. (1998). Where Along a River's Length Will Vegetation Most Effectively Stabilise Stream Banks? Geomorphology, 23(1), 55-75.

Alfred, T. (2009). Colonialism and State Dependency. Journal of Aboriginal Health, 5, 42-60.

Alfred, T. (2015). Cultural Strength: Restoring the Place of Indigenous Knowledge in Practice and Policy. Australian Aboriginal Studies, 1, 3.

Anderson, A. (2002). A Fragile Plenty: Pre-European Maori and the New Zealand Environment. In Environmental Histories of New Zealand. Auckland: Oxford University Press.

Anderson, A. (2003). Prodigious Birds: Moas and Moa-Hunting in New Zealand. Christchurch: Cambridge University Press.

Arnaud, F., Piégay, H., Schmitt, L., Rollet, A. J., Ferrier, V., \& Béal, D. (2015). Historical Geomorphic Analysis (1932-2011) of a By-Passed River Reach in Process-Based Restoration Perspectives: The Old Rhine Downstream of the Kembs Diversion Dam (France, Germany). Geomorphology, 236, 163-177.

Baldwin, A., Cameron, L., \& Kobayashi, A. (2011). Rethinking the Great White North: Race, Nature, and the Historical Geographies of Whiteness in Canada. UBC Press. Retrieved August 12, 2017, from https://books.google.co.nz/boo ks?hl=en\&lr=\&id=V8UyF3vufhsC\&oi=fnd\&pg=PP2\&dq=Catriona+Sandil and $s+\mathrm{Cape}+\mathrm{B}$ reto n \& ot s = k F z ZM 2 Wo B e \& sig $=6$ I q c q $S$ IIp_hYLJicdELYKVWDLlc.

Baranyovits, A. (2017). Urban Ecology of an Endemic Pigeon, the Kererū. PhD Thesis, University of Auckland, Auckland.

Barber, M., \& Jackson, S. (2015). Remembering 'the Blackfellows' Dam': Australian Aboriginal Water Management and Settler Colonial Riparian Law in the Upper Roper River, Northern Territory. Settler Colonial Studies, 5(4), 282-301.

Bardsley, D. K., \& Wiseman, N. D. (2016). Socio-Ecological Lessons for the Anthropocene: Learning from the Remote Indigenous Communities of Central Australia. Anthropocene, 14, 58-70.

Barta, T. (2008). Decent Disposal: Australian Historians and the Recovery of Genocide. In The Historiography of Genocide (pp. 296-322). Springer. 
Bashford, P. A. (2013). The Anthropocene Is Modern History: Reflections on Climate and Australian Deep Time. Australian Historical Studies, 44(3), 341-349.

Bauman, W. A., \& O'Brien, K. J. (2019). Environmental Ethics and Uncertainty: Wrestling with Wicked Problems. New York: Routledge.

Beilin, R., \& West, S. (2016). Performing Natures: Adaptive Management Practice in the "Externally Unfolding Present". In L. Head, K. Saltzman, G. Setten, \& M. Stenseke (Eds.), Nature, Temporality and Environmental Management: Scandinavian and Australian Perspectives on Peoples and Landscapes (pp. 186-203). London; New York: Routledge.

Bell, R. E. (1996). Seed Dispersal by Kereru (Hemiphaga Novaeseelandiae) at Wenderholm Regional Park. Thesis, University of Auckland.

Bell, A. (2014). Relating Indigenous and Settler Identities: Beyond Domination. London: Palgrave Macmillan UK.

Beller, E. E., Downs, P. W., Grossinger, R. M., Orr, B. K., \& Salomon, M. N. (2016). From Past Patterns to Future Potential: Using Historical Ecology to Inform River Restoration on an Intermittent California River. Landscape Ecology, 31(3), 581-600.

Beller, E. E., McClenachan, L., Zavaleta, E. S., \& Larsen, L. G. (2020). Past Forward: Recommendations from Historical Ecology for Ecosystem Management. Global Ecology and Conservation, 21, e00836.

Bennett, B. M., \& van Sittert, L. (2019). Historicising Perceptions and the National Management Framework for Invasive Alien Plants in South Africa. Journal of Environmental Management, 229, 174-181.

Bhatt, J. P., Manish, K., Mehta, R., \& Pandit, M. K. (2016). Assessing Potential Conservation and Restoration Areas of Freshwater Fish Fauna in the Indian River Basins. Environmental Management, 57(5), 1098-1111.

Bird, M. Y. (1999). What We Want to Be Called: Indigenous Peoples' Perspectives on Racial and Ethnic Identity Labels. American Indian Quarterly, 23(2), 1-21.

Boswijk, G., Fowler, A., \& Palmer, J. (2005). Hidden Histories: Tree-Ring Analysis of late Holocene Swamp Kauri, Waikato, New Zealand, 9.

Brookshire, D., \& Kaza, N. (2013). Planning for Seven Generations: Energy Planning of American Indian Tribes. Energy Policy, 62, 1506-1514.

Callicott, J. B. (2002). Choosing Appropriate Temporal and Spatial Scales for Ecological Restoration. Journal of Biosciences, 27(4), 409-420. 
Cameron, E. S. (2015). Far Off Metal River: Inuit Lands, Settler Stories, and the Makings of the Contemporary Arctic. Vancouver: UBC Press.

Campbell, J. (2007). Invisible Invaders: Smallpox and Other Diseases in Aboriginal Australia, 1780-1880. Carlton South, VIC: Melbourne University Press.

Carpenter, J. K. (2019). Legacy of Loss: Seed Dispersal by Kererü and Flightless Birds in New Zealand. PhD Thesis, University of Canterbury, Christchurch.

Carroll, C. (2015). Roots of Our Renewal: Ethnobotany and Cherokee Environmental Governance. Minneapolis: University of Minnesota Press.

Carter, L. (2019). He Korowai o Matainaka/The Cloak of Matainaka: Traditional Ecological Knowledge in Climate Change Adaptation - Te Wai Pounamu, New Zealand. New Zealand Journal of Ecology, 43(3), 1-8.

Clément, V. (2017). Dancing Bodies and Indigenous Ontology: What Does the Haka Reveal About the Māori Relationship with the Earth? Transactions of the Institute of British Geographers, 42(2), 317-328.

Clements, F. E. (1916). Plant Succession: An Analysis of the Development of Vegetation. Washington, DC: Carnegie Institution of Washington.

Clements, F. E. (1936). Nature and Structure of the Climax. Journal of Ecology, 24(1), 252-284.

Clover, K., \& Historical Society of the Hauraki Plains. (2007). Taming of the Hauraki Swamp: Stories of Some of the Pioneers Who Lived on the Hauraki Plains and Whose Lives Have Been Influential in Converting the Area from Swamp to Farms. Ngatea [N.Z.]: Historical Society of the Hauraki Plains.

Connelly, N. A., \& Knuth, B. A. (2002). Using the Coorientation Model to Compare Community Leaders' and Local Residents' Views About Hudson River Ecosystem Restoration. Society \& Natural Resources, 15(10), 933-948.

Corntassel, J., \& Bryce, C. (2011). Practicing Sustainable SelfDetermination: Indigenous Approaches to Cultural Restoration and Revitalization Indigenous Political Actors. Brown Journal of World Affairs, 18(2), 151-166.

Crow, S. K., Tipa, G. T., Booker, D. J., \& Nelson, K. D. (2018). Relationships Between Maori Values and Streamflow: Tools for Incorporating Cultural Values into Freshwater Management Decisions. New Zealand Journal of Marine and Freshwater Research, 52(4), 626-642.

Crow, S. K., Tipa, G. T., Nelson, K. D., \& Whitehead, A. L. (2020). Incorporating Māori Values into Land Management Decision Tools. New Zealand Journal of Marine and Freshwater Research, 1-18. 
Cunsolo, A., \& Ellis, N. R. (2018). Ecological Grief as a Mental Health Response to Climate Change-Related Loss. Nature Climate Change, 8(4), 275.

Davenport, M. A., Bridges, C. A., Mangun, J. C., Carver, A. D., Williard, K. W., \& Jones, E. O. (2010). Building Local Community Commitment to Wetlands Restoration: A Case Study of the Cache River Wetlands in Southern Illinois, USA. Environmental Management, 45(4), 711-722.

Davis, H., \& Todd, Z. (2017). On the Importance of a Date, or Decolonizing the Anthropocene. ACME: An International E-Journal for Critical Geographies, 16(4).

Dawson, C. (2015). Wai Tangi, Waters of Grief, Wai Ora, Waters of Life: Rivers, Reports, and Reconciliation in Aotearoa New Zealand. Ecocriticism of the Global South, 93.

de Leeuw, S., \& Hunt, S. (2018). Unsettling Decolonizing Geographies. Geography Compass, 12(7), e12376.

Denny, S. K., \& Fanning, L. M. (2016). A Mi'kmaw Perspective on Advancing Salmon Governance in Nova Scotia, Canada: Setting the Stage for Collaborative Co-existence. International Indigenous Policy Journal; London, 7(3) Retrieved June 18, 2020, from http://search.proquest.com/ docview/1858128395/abstract/288C64E807CE45C6PQ/1.

District Commissioner of Works. (1958). District Commissioner of Works to Commissioner of Works, 3 March 1958, AATE A1002 5113 13/125/1, Archives New Zealand Auckland.

Diver, S. (2012). Columbia River Tribal Fisheries: Life History Stages of a Co-management Institution. In Keystone Nations: Indigenous Peoples and Salmon Across the North Pacific. School for Advanced Research Press, Santa Fe, New Mexico, USA (pp. 207-235). Santa Fe: SAR Press.

Durie, M. H. (1998). Te Mana, Te Käwanatanga: the Politics of SelfDetermination. Auckland: Oxford University Press.

Ellinghaus, K. (2009). Biological Absorption and Genocide: A Comparison of Indigenous Assimilation Policies in the United States and Australia. Genocide Studies and Prevention. Retrieved May 17, 2020, from https://www.utpjournals.press/doi/abs/10.3138/gsp.4.1.59.

Elliot, R. (1997). Faking Nature: The Ethics of Environmental Restoration. London; New York: Routledge.

Ens, E. J., Finlayson, M., Preuss, K., Jackson, S., \& Holcombe, S. (2012). Australian Approaches for Managing 'Country' Using Indigenous and NonIndigenous Knowledge. Ecological Management \& Restoration, 13(1), 100-107. 
Failing, L., Gregory, R., \& Higgins, P. (2013). Science, Uncertainty, and Values in Ecological Restoration: A Case Study in Structured Decision-Making and Adaptive Management. Restoration Ecology, 21(4), 422-430.

Fernández-Manjarrés, J. F., Roturier, S., \& Bilhaut, A.-G. (2018). The Emergence of the Social-Ecological Restoration Concept. Restoration Ecology, 26(3), 404-410.

Fitzmaurice, A. (2007). The Genealogy of Terra Nullius. Australian Historical Studies, 38(129), 1-15.

Flannery, T. (2002). The Future Eaters: An Ecological History of the Australasian Lands and People. New York: Grove Press.

Forster, M. E. (2012). Hei Whenua Papatipu: Kaitiakitanga and the Politics of Enhancing the Mauri of Wetlands. Doctor of Philosophy, Massey University, Palmerston North.

Fox, C. A., Reo, N. J., Turner, D. A., Cook, J., Dituri, F., Fessell, B., et al. (2017). "The River Is Us; The River Is in Our Veins": Re-Defining River Restoration in Three Indigenous Communities. Sustainability Science, 1-13.

Giblett, R. (2009). Wilderness to Wasteland in the Photography of the American West. Continuum, 23(1), 43-52.

Hall, M. (2005). Earth Repair: A Transatlantic History of Environmental Restoration. Charlottesville: University of Virginia Press.

Hamilton, D. P., Collier, K. J., Quinn, J. M., \& Howard-Williams, C. (2018). Lake Restoration Handbook: A New Zealand Perspective. Cham: Springer.

Harmsworth, G., \& Roskruge, N. (2014). Indigenous Maori Values, Perspectives, and Knowledge of Soils in Aotearoa-New Zealand. In The Soil Underfoot: Infinite Possibilities for a Finite Resource. Boca Raton, FL: CRC Press, Taylor \& Francis Group.

Head, L. (2012). Decentring 1788: Beyond Biotic Nativeness. Geographical Research, 50(2), 166-178.

Head, L., \& Muir, P. (2004). Nativeness, Invasiveness, and Nation in Australian Plants. Geographical Review, 94(2), 199-217.

Higgs, E. (2003). Nature by Design: People, Natural Process, and Ecological Restoration. Cambridge, MA: MIT Press.

Higgs, E., Falk, D. A., Guerrini, A., Hall, M., Harris, J., Hobbs, R. J., et al. (2014). The Changing Role of History in Restoration Ecology. Frontiers in Ecology and the Environment, 12(9), 499-506.

Hikuroa, D., Slade, A., \& Gravley, D. (2011). Implementing Māori Indigenous Knowledge (Mātauranga) in a Scientific Paradigm: Restoring the Mauri to Te Kete Poutama. MAI Review, 3(1), 9. 
Hobbs, R. J. (2013). Grieving for the Past and Hoping for the Future: Balancing Polarizing Perspectives in Conservation and Restoration. Restoration Ecology, 21(2), 145-148.

Hourdequin, M., \& Havlick, D. G. (2016). Restoring Layered Landscapes: History, Ecology, and Culture. New York: Oxford University Press.

Humphries, P., \& Winemiller, K. O. (2009). Historical Impacts on River Fauna, Shifting Baselines, and Challenges for Restoration. BioScience, 59(8), 673-684.

Iwi Rep 3. (2020, February 13). Interview with Iwi Representative 3.

Iwi Rep 4. (2020, February 14). Interview with Iwi Representative 4.

Iwi Rep 5. (2019, March 25). Interview with Interview Iwi Representative 5.

Iwi Rep 6. (2020, February 14). Interview with Iwi Representative 6.

Iwi Rep 7. (2019a, May 16). Interview with Iwi Representative 7.

Iwi Rep 7. (2019b, June 13). Interview with Iwi Representative 7.

Iwi Rep 8. (2019, October 9). Interview with Iwi Representative 8.

Jacobson, R. B., Janke, T. P., \& Skold, J. J. (2011). Hydrologic and Geomorphic

Considerations in Restoration of River-Floodplain Connectivity in a Highly

Altered River System, Lower Missouri River, USA. Wetlands Ecology and Management, 19(4), 295-316.

Jordan, W. R. (2003). The Sunflower Forest: Ecological Restoration and the New Communion with Nature. University of California Press.

Jordan, W. R., \& Lubick, G. M. (2011). Making Nature Whole: A History of Ecological Restoration. Washington; London: Island Press.

Kaitiaki 1. (2020, February 4). Interview with Kaitiaki 1.

Kaitiaki 2. (2020, February 4). Interview with Kaitiaki 2.

Kaitiaki 3. (2020, February 5). Interview with Kaitiaki 3.

Kaitiaki 4. (2020, February 5). Interview with Kaitiaki 4.

Kaitiaki 5. (2020, February 5). Interview with Kaitiaki 5.

Katz, E., \& Light, A. (2013). Environmental Pragmatism. Routledge.

Kelm, M.-E. (1999). Colonizing Bodies: Aboriginal Health and Healing in British Columbia, 1900-50. British Columbia: UBC Press.

Kibler, K., Cook, G., Chambers, L., Donnelly, M., Hawthorne, T., Rivera, F., \& Walters, L. (2018). Integrating Sense of Place into Ecosystem Restoration: A Novel Approach to Achieve Synergistic Social-Ecological Impact. Ecology and Society, 23(4).

King, J. T. (2006). The Value of Water and the Meaning of Water Law for the Native Americans Known as the Haudenosaunee. Cornell Journal of Law and Public Policy, 16, 449. 
Kukutai, T. (2013). The Structure of Urban Maori Identities. Indigenous in the City: Contemporary Identities and Cultural Innovation, 311-333.

Kurashima, N., Jeremiah, J., \& Ticktin, T. (2017). I Ka Wā Ma Mua: The Value of a Historical Ecology Approach to Ecological Restoration in Hawai' i. Pacific Science, 71(4), 437-456.

Lake, P. S., Bond, N., \& Reich, P. (2017). Chapter 5.4 - Restoration Ecology of Intermittent Rivers and Ephemeral Streams. In T. Datry, N. Bonada, \& A. Boulton (Eds.), Intermittent Rivers and Ephemeral Streams (pp. 509-533). London: Academic.

Langton, M. (2006). Settling with Indigenous People: Modern Treaty and Agreement-Making. Annandale, NSW: Federation Press.

Leonard, S., Parsons, M., Olawsky, K., \& Kofod, F. (2013). The Role of Culture and Traditional Knowledge in Climate Change Adaptation: Insights from East Kimberley, Australia. Global Environmental Change, 23(3), 623-632.

Lidström, S., West, S., Katzschner, T., Pérez-Ramos, M. I., \& Twidle, H. (2016). Invasive Narratives and the Inverse of Slow Violence: Alien Species in Science and Society. Environmental Humanities, 7(1), 1-40.

Light, A. (1994). I. Hegemony and Democracy: How Politics in Restoration Informs the Politics of Restoration. Restoration \& Management Notes, 12(2), 140-144.

Long, J. W., Goode, R. W., Gutteriez, R. J., Lackey, J. J., \&Anderson, M. K. (2017). Managing California Black Oak for Tribal Ecocultural Restoration. Journal of Forestry, 115(5), 426-434.

MacGregor, S. (2014). Only Resist: Feminist Ecological Citizenship and the Post-Politics of Climate Change. Hypatia, 29(3), 617-633.

Maniapoto Maori Trust Board. (2017). Review of the Deed In Relation to the Co-Governance and Co-Management of the Waipa River. Maniapoto Maori Trust Board.

Māori Business Owner 1. (2019, August 29). Māori Business Owner 1. Marshall, K., Koseff, C., Roberts, A., Lindsey, A., Kagawa-Viviani, A., Lincoln, N., \& Vitousek, P. (2017). Restoring People and Productivity to Puanui: Challenges and Opportunities in the Restoration of an Intensive Rain-Fed Hawaiian Field System. Ecology and Society, 22(2).

McCormack, F. (2012). Indigeneity as Process: Māori Claims and Neoliberalism. Social Identities, 18(4), 417-434.

McDonald, T., Gann, G. D., Jonson, J., \& Dixon, K. W. (2018). International Standards for the Practice of Ecological Restoration - Including Principles and Key Concepts (p. 48). Washington, DC: Society for Ecological Restoration. 
McGregor, D. (2014). Traditional Knowledge and Water Governance: The Ethic of Responsibility. AlterNative: An International Journal of Indigenous Peoples, 10(5), 493-507.

McGregor, D. (2018). Indigenous Environmental Justice, Knowledge, and Law. Kalfou, 5(2), 279.

McLeod, N.C. (1964). District Commissioner of Works N.C. McLeod to Walsh, 29 September 1964, R17280156, AATE 5113 A1002, 321/a, 13/125/1, Archives New Zealand, Auckland.

Metge, J., \& Kinloch, P. (2014). Talking Past Each Other: Problems of Cross Cultural Communication. Wellington: Victoria University Press.

Moran, S. (2010). Cities, Creeks, and Erasure: Stream Restoration and Environmental Justice. Environmental Justice, 3(2), 61-69.

Morandi, B., Piégay, H., Lamouroux, N., \& Vaudor, L. (2014). How Is Success or Failure in River Restoration Projects Evaluated? Feedback from French Restoration Projects. Journal of Environmental Management, 137, 178-188.

NIWA. (2014). Maniapoto Priorities for the Restoration of the Waipa River Catchment. Wellington: NIWA.

Norgaard, K. M., Reed, R., \& Bacon, J. M. (2018). How Environmental Decline Restructures Indigenous Gender Practices: What Happens to Karuk Masculinity When There Are No Fish? Sociology of Race and Ethnicity, 4(1), 98-113.

Nursey-Bray, M. (2016). Cultural Indicators, Country and Culture: The Arabana, Change and Water. The Rangeland Journal, 37(6), 555-569.

Nursey-Bray, M., \& Palmer, R. (2018). Country, Climate Change Adaptation and Colonisation: Insights from an Indigenous Adaptation Planning Process, Australia. Heliyon, 4(3), e00565.

Palmer, M. A., Bernhardt, E. S., Allan, J. D., Lake, P. S., Alexander, G., Brooks, S., et al. (2005). Standards for Ecologically Successful River Restoration: Ecological Success in River Restoration. Journal of Applied Ecology, 42(2), 208-217.

Palmer, M. A., Filoso, S., \& Fanelli, R. M. (2014). From Ecosystems to Ecosystem Services: Stream Restoration as Ecological Engineering. Ecological Engineering, 65, 62-70.

Palmer, M. A., Zedler, J. B., \& Falk, D. A. (2016). Ecological Theory and Restoration Ecology. In M. A. Palmer, J. B. Zedler, \& D. A. Falk (Eds.), Foundations of Restoration Ecology (pp. 3-26). Washington, DC: Island Press/ Center for Resource Economics. 
Panelli, R., \& Tipa, G. (2007). Placing Well-Being: A Maori Case Study of Cultural and Environmental Specificity. EcoHealth, 4(4), 445-460.

Park, G. (2018). Nga Uruora. Wellington: Victoria University Press.

Parsons, M. (2010). Defining Disease, Segregating Race: Sir Raphael Cilento, Aboriginal Health and Leprosy Management in Twentieth Century Queensland. Aboriginal History, 85-114.

Paterson-Shallard, H., Fisher, K., Parsons, M., \& Makey, L. (2020). Holistic Approaches to River Restoration in Aotearoa New Zealand. Environmental Science \& Policy, 106, 250-259.

Pearce, L. (2019). Critical Histories for Ecological Restoration. Thesis, Australian National University, Canberra. Retrieved June 8, 2020, from https://search. proquest.com/docview/2343447929/?pq-origsite=primo.

Perring, M. P., Standish, R. J., Price, J. N., Craig, M. D., Erickson, T. E., Ruthrof, K. X., et al. (2015). Advances in Restoration Ecology: Rising to the Challenges of the Coming Decades. Ecosphere, 6(8), 1-5.

Peters, M. A., Hamilton, D., \& Eames, C. (2015). Action on the Ground: A Review of Community Environmental Groups' Restoration Objectives, Activities and Partnerships in New Zealand. New Zealand Journal of Ecology, 39(2), 179.

Pluymers, K. (2011). Taming the Wilderness in Sixteenth- and SeventeenthCentury Ireland and Virginia. Environmental History, 16(4), 610-632.

Pouliot, A. (2016). A Thousand Days in the Forest: An Ethnography of the Culture of Fungi.

Ratana, K., Herangi, N., \& Murray, T. (2019). Me pēhea te whakarauora i ngā repo o Ngāti Maniapoto? How Do We Go About Restoring the Wetlands of Ngāti Maniapoto? New Zealand Journal of Ecology, 43(3), 1-12.

Reyes-García, V., Fernández-Llamazares, Á., McElwee, P., Molnár, Z., Öllerer, K., Wilson, S. J., \& Brondizio, E. S. (2019). The Contributions of Indigenous Peoples and Local Communities to Ecological Restoration. Restoration Ecology, 27(1), 3-8.

Rose, D. B. (2004). Reports from a Wild Country: Ethics for Decolonisation. Sydney: University of New South Wales Press.

Salmond, A. (2014). Tears of Rangi: Water, Power, and People in New Zealand. HAU: Journal of Ethnographic Theory, 4(3), 285-309.

Saulters, O. (2014). Undam It? Klamath Tribes, Social Ecological Systems, and Economic Impacts of River Restoration. American Indian Culture and Research Journal, 38(3), 25-54.

Schotborgh, H. M. (2005). An Analysis of Home Ranges, Movements, Foods, and Breeding of Kereru (Hemiphaga novaeseelandiae) in a Rural-Urban Landscape 
on Banks Peninsula, New Zealand. Thesis, Lincoln University. Retrieved July 4, 2020, from https://researcharchive.lincoln.ac.nz/handle/10182/2681. Schuelke, N. (2014). Urban River Restoration and Environmental Justice: Addressing Flood Risk Along Milwaukee's Kinnickinnic River. Thesis, The University of Wisconsin - Milwaukee, Milwaukee (Wisconsin). Retrieved July 4, 2020, from http://search.proquest.com/docview/1617457744/ abstract/C58A60BB963D422EPQ/2.

Scientist 2. (2019, November 7). Interview with Scientist 2.

Senos, R., Lake, F. K., Turner, N., \& Martinez, D. (2006). Traditional Ecological Knowledge and Restoration Practice. In D. Apostol \& M. Sinclair (Eds.), Restoring the Pacific Northwest: The Art and Science of Ecological Restoration in Cascadia (pp. 393-496). Washington, DC: Island Press.

Statistics New Zealand. (2020). Livestock Numbers. Statistics New Zealand. Government. Retrieved August 3, 2020, from https://www.stats.govt.nz/ indicators/livestock-numbers.

Steffen, W., Persson, Å., Deutsch, L., Zalasiewicz, J., Williams, M., Richardson, K., et al. (2011). The Anthropocene: From Global Change to Planetary Stewardship. AMBIO, 40(7), 739.

Steffen, W., Broadgate, W., Deutsch, L., Gaffney, O., \& Ludwig, C. (2015). The Trajectory of the Anthropocene: The Great Acceleration. The Anthropocene Review, 2(1), 81-98.

Stein, E. D., Dark, S., Longcore, T., Grossinger, R., Hall, N., \& Beland, M. (2010). Historical Ecology as a Tool for Assessing Landscape Change and Informing Wetland Restoration Priorities. Wetlands, 30(3), 589-601.

Stokes, E. (2000). The Legacy of Ngatoroirangi: Maori Customary Use of Geothermal Resources. Department of Geography, University of Waikato. Retrieved June 20, 2018, from https://researchcommons.waikato.ac.nz/ handle/10289/6323.

Te Aho, L. (2010). Attempting to Integrate Indigenous Traditional Knowledge of Waterways with Western Science: To Restore and Protect the Health and Well-Being of an Ancestral River. In 4th International Traditional Knowledge Conference 2010 (p. 328).

Te Aho, L. (2019). Te Mana o te Wai: An Indigenous Perspective on Rivers and River Management. River Research and Application, 35(10), 1615-1621.

Tipa, G., \& Nelson, K. (2017). Eco-Cultural Restoration Across Multiple Spatial Scales: A New Zealand Case Study. Water History, 9(1), 87-106.

Tipa, G., \& Teirney, L. (2006). A Cultural Health Index for Streams and Waterways: A Tool for Nationwide Use. Wellington: Ministry for the Environment. 
Tobias, J. K., \& Richmond, C. A. (2014). "That Land Means Everything to Us as Anishinaabe....": Environmental Dispossession and Resilience on the North Shore of Lake Superior. Health \& Place, 29, 26-33.

Todd, Z. (2014). Fish Pluralities: Human-Animal Relations and Sites of Engagement in Paulatuuq, Arctic Canada. Études/Inuit/Studies, 38(1-2), 217-238.

Turner, N. J., \& Clifton, H. (2009). “It's So Different Today”: Climate Change and Indigenous Lifeways in British Columbia, Canada. Global Environmental Change, 19(2), 180-190.

Uprety, Y., Asselin, H., Bergeron, Y., Doyon, F., \& Boucher, J. F. (2012). Contribution of Traditional Knowledge to Ecological Restoration: Practices and Applications. Ecoscience, 19(3), 225-237.

van Dooren, T. (2014). Flight Ways: Life and Loss at the Edge of Extinction. New York: Columbia University Press.

Veracini, L. (2010). Settler Colonialism: A Theoretical Overview.

New York: Springer.

von Wehrden, H., Hanspach, J., Kaczensky, P., Fischer, J., \& Wesche, K. (2012). Global Assessment of the Non-Equilibrium Concept in Rangelands. Ecological Applications, 22(2), 393-399.

Waikato Regional Council. (2012). Waipā Zone Management Plan. Hamilton: Waikato Regional Council.

Waikato Regional Council. (2014). Waipā Catchment Plan. Hamilton: Waikato Regional Council.

Waltham, N. J., Barry, M., McAlister, T., Weber, T., \& Groth, D. (2014). Protecting the Green Behind the Gold: Catchment-Wide Restoration Efforts Necessary to Achieve Nutrient and Sediment Load Reduction Targets in Gold Coast City, Australia. Environmental Management, 54(4), 840-851.

Wanhalla, A. (2015). In/Visible Sight: The Mixed-Descent Families of Southern New Zealand. Wellington: Bridget Williams Books.

Watts, V. (2013). Indigenous Place-Thought and Agency Amongst Humans and Non Humans (First Woman and Sky Woman Go On a European World Tour!). Decolonization: Indigeneity, Education \& Society, 2(1) Retrieved May 16, 2020, from https://jps.library.utoronto.ca/index.php/des/article/view/19145. Weber, C., Åberg, U., Buijse, A. D., Hughes, F. M. R., McKie, B. G., Piégay, H., et al. (2018). Goals and Principles for Programmatic River Restoration Monitoring and Evaluation: Collaborative Learning Across Multiple Projects: Programmatic River Restoration Monitoring and Evaluation. Wiley Interdisciplinary Reviews: Water, 5(1), e1257. 
Wehi, P. M., \& Lord, J. M. (2017). Importance of Including Cultural Practices in Ecological Restoration. Conservation Biology, 31(5), 1109-1118.

Wehi, P. M., Beggs, J. R., \& McAllister, T. G. (2019). Ka mua, ka muri: The Inclusion of Mātauranga Māori in New Zealand Ecology. New Zealand Journal of Ecology, 43(3), 1-8.

White, C. A., Perrakis, D. D. B., Kafka, V. G., \& Ennis, T. (2011). Burning at the Edge: Integrating Biophysical and Eco-Cultural Fire Processes in Canada's Parks and Protected Areas. Fire Ecology, 7(1), 74-106.

Whyte, K. (2017). Indigenous Climate Change Studies: Indigenizing Futures, Decolonizing the Anthropocene. English Language Notes, 55(1), 153-162.

Whyte, K. (2018). Settler Colonialism, Ecology, and Environmental Injustice. Environment and Society, 9(1), 125-144. https://doi.org/10.3167/ ares.2018.090109.

Winter, C. J. (2018). The Paralysis of Intergenerational Justice: Decolonising Entangled Futures. Retrieved January 11, 2020, from https://ses.library.usyd. edu.au/handle/2123/18009.

Winter, C. J. (2019). Does Time Colonise Intergenerational Environmental Justice Theory? Environmental Politics, 1-19.

Open Access This chapter is licensed under the terms of the Creative Commons Attribution 4.0 International License (http://creativecommons.org/licenses/ by/4.0/), which permits use, sharing, adaptation, distribution and reproduction in any medium or format, as long as you give appropriate credit to the original author(s) and the source, provide a link to the Creative Commons licence and indicate if changes were made.

The images or other third party material in this chapter are included in the chapter's Creative Commons licence, unless indicated otherwise in a credit line to the material. If material is not included in the chapter's Creative Commons licence and your intended use is not permitted by statutory regulation or exceeds the permitted use, you will need to obtain permission directly from the copyright holder.

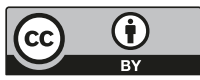

